\title{
Extensive hydrothermal activity revealed by multi-tracer survey in the Wallis and Futuna region (SW Pacific)
}

\author{
Konn Cecile ${ }^{1,}{ }^{*}$, Fourré E. ${ }^{3}$, Jean-Baptiste P. ${ }^{3}$, Donval Jean-Pierre ${ }^{1}$, Guyader Vivien ${ }^{1}$, \\ Birot Dominique ${ }^{1}$, Alix Anne-Sophie ${ }^{1}$, Gaillot Arnaud ${ }^{2}$, Perez Florian ${ }^{3}$, Dapoigny A. ${ }^{3}$, Pelleter Ewan ${ }^{1}$, \\ Resing J.A. ${ }^{4}$, Charlou Jean-Luc ${ }^{1}$, Fouquet Yves ${ }^{1}$
}

${ }^{1}$ Ifremer,Laboratoire des Cycles Géochimiques et ressources, CS10070,F-29280Plouzané, France

2 Ifremer,Service Cartographie Traitement de Données et Instrumentation, CS10070,F-29280Plouzané, France

${ }^{3}$ LSCE,UMR 8212CEA-CNRS-UVSQ, F-91191Gif-sur-Yvette, France

4 Joint Institute for the Study of the Atmosphere and the Ocean, University of Washington and NOAA-

PMEL, 7600Sand Point Way NE, Seattle, Washington 98115, USA

* Corresponding author : Cecile Konn, email address : cecile.konn@ifremer.fr

\begin{abstract}
:
The study area is close to the Wallis and Futuna Islands in the French EEZ. It exists on the western boundary of the fastest tectonic area in the world at the junction of the Lau and North-Fiji basins. At this place, the unstable back-arc accommodates the plate motion in three ways: (i) the north Fiji transform fault, (ii) numerous unstable spreading ridges, and (iii) large areas of recent volcanic activity. This instability creates bountiful opportunity for hydrothermal discharge to occur. Based on geochemical (CH4, TDM, 3He) and geophysical (nephelometry) tracer surveys: (1) no hydrothermal activity could be found on the Futuna Spreading Center (FSC) which sets the western limit of hydrothermal activity; (2) four distinct hydrothermal active areas were identified: Kulo Lasi Caldera, Amanaki Volcano, Fatu Kapa and Tasi Tulo areas; (3) extensive and diverse hydrothermal manifestations were observed and especially a 2D distribution of the sources. At Kulo Lasi, our data and especially tracer ratios $(\mathrm{CH} 4 / 3 \mathrm{He}$ $\sim 50 \times 106$ and $\mathrm{CH} 4 / \mathrm{TDM} \sim 4.5$ ) reveal a transient $\mathrm{CH} 4$ input, with elevated levels of $\mathrm{CH} 4$ measured in 2010, that had vanished in 2011 (Futuna 2), most likely caused by an eruptive magmatic event. By contrast at Amanaki, vertical tracer profiles and tracer ratios point to typical seawater / basalt interactions. Fatu Kapa is characterized by a substantial spatial variability of the hydrothermal water column anomalies, most likely due to widespread focused and diffuse hydrothermal discharge in the area. In the Tasi Tulo zone, the hydrothermal signal is characterized by a total lack of turbidity, although other tracer anomalies are in the same range as in nearby Fatu Kapa. The background data set revealed the presence of a $\mathrm{Mn}$ and $3 \mathrm{He}$ chronic plume due to the extensive and cumulative venting over the entire area. To that respect, we believe that the joined domain composed of our active area and the nearby active area discovered in the East by Lupton et al. (2012) highly contribute to the extensive Tonga-Fiji plume and which thus may not originate from a sole source near the Samoa. Our results also emphasize and support the idea that back-arc hydrothermal systems have a significant input to the regional and global ocean and maybe more important than their MOR analogues.
\end{abstract}




\section{Highlights}

- Extensive and diverse hydrothermal activity in the SW-Pacific. - Importance of back-arc hydrothermal systems for the global ocean chemistry and biogeochemical cycles. ${ }^{3} \mathrm{He}$ Tonga-Fiji regional plume. FSC sets the western boundary of the hydrothermally active zone.

\section{Introduction}

Most Volcanogenic Massive Sulphides (VMS) deposits mined on land are found in arc / back-arc types of environments indicating that oceanic arc and back-arc systems are first order environments that generate hydrothermal systems and their associated VMS deposits (Franklin et al., 2005; Galley et al., 2007). The first evidence of inactive hydrothermal deposits in the SW Pacific, consisting of silica and barite, was reported on the Peggy Ridge east of the Fiji Islands (Bertine and Keene, 1975). Inactive sulphide deposits were also 
discovered in the northern Lau Basin (Hawkins and Helu, 1986). Active hydrothermal venting has known to occur in arc and back-arc settings since 1986 (Both et al., 1986). In the late 1980s, hydrothermal activity in back-arc environments were discovered in the Okinawa trough (Halbach et al., 1989), the Manus Basin (Binns and Scott, 1993; Both et al., 1986), the Mariana basin (Craig et al., 1987; Urabe and Kusakabe, 1990), and the North Fiji Basin (Auzende et al., 1989; Bendel et al., 1993). The first evidence of hydrothermal deposits in the southern Lau Basin was obtained in 1984 (Von Stackelberg, 1988). Active venting in the Southern Lau Basin (Vai Lili and Hine Hina vents) was discovered in 1989 (Fouquet et al., 1991; Fouquet et al., 1993). More recently many other vent fields presenting a great diversity have been identified in the Lau, North Fiji and Manus basins as well as along the Marianna and mid-Kermadec arcs (e.g. Baker et al., 2005; Baker et al., 2006; de Ronde et al., 2007; Embley et al., 2004; Gamo et al., 1993; German et al., 2006; Lisitzin et al., 1997; Lupton et al., 2012; Lupton et al., 2004; Massoth et al., 2007; Resing et al., 2009). The complex tectonic setting of the arc / back-arc system and the diversity in magma composition especially magmas with higher water contents with respect to Mid-Ocean Ridge Basalt (MORB) generates a large variety of hydrothermal systems in back-arc environments. Notably arc magmas release a broad range of volatiles and the resultant hydrothermal fluids discharging into the water column are geochemically diverse (e.g Bézos et al., 2009; Mottl et al., 2011; Reeves et al., 2011; Sinton et al., 2003). Despite growing evidence for extensive hydrothermal activity in arc / back-arc environments, knowledge of the distribution and frequency of hydrothermal processes at back-arc spreading centers is much less compared to Mid-Ocean Ridges (MOR) and many areas remain to be surveyed (e.g. Baker et al., 2004; Baker et al., 1995; Baker et al., 2008; German and Parson, 1998).

To that respect, the Tonga-New Hebrides region deserves special attention. It is characterised by a complex geodynamical setting related to the development of the opposite- 
facing Tonga and New Hebrides subduction zones and the associated Lau and North-Fiji back-arc basins (Pelletier et al., 1998) (Figure 1). The northern Lau Basin is situated at the transition between the North Fiji fracture zone and the Tonga trench and represents a key area of the Pacific-Australia plate boundary. The estimated overall opening rates are the fastest recorded in the earth with ca. $160 \mathrm{~mm} / \mathrm{y}$. This high rate extension is accommodated by two spreading centers (Northweast Lau spreading center - NWLSC; Northeast Lau spreading center - NELSC), several rifts and pull-apart basins (Arculus et al., 2008, Lupton et al., 2012; Pelletier et al., 1998)). This complex structure is clearly driven by the rapid subduction of the Pacific Plate $(240 \mathrm{~mm} / \mathrm{y})$ which more likely results in the roll back of the slab and the inflow of the Samoan hot and fertile mantle (Wiens et al., 2006). In contrast to classical MOR settings, the northern Lau Basin hosts a wide variety of magmatic products reflecting either the diversity of mantle sources (ex. depleted MOR-type mantle and fertile hot spot-type mantle) or the complexity of magmatic processes related to diffuse volcanic activity (Labanieh et al., 2011; Lupton et al., 2015). This situation creates particularly unstable areas where an unusual number of spreading centers and major regional transform faults accommodate back-arc extension (Pelletier et al., 1998, 2001) (Figure 1). Altogether, these structural and magmatic features are favourable to the establishment of widespread and geochemically diverse hydrothermal systems with both high-temperature (high-T) and diffuse low-temperature (low-T) hydrothermal venting.

In this key area Lupton et al. (2004) reported the presence of an extensive hydrothermal ${ }^{3}$ He plume originating somewhere near the Samoan hotspot. This major basin-scale plume is similar to the plume generated by the super fast East Pacific Rise and indicates an area of intense hydrothermal activity. Although there are several sites of volcanic activity in the Tonga-Fiji region that may host hydrothermal activity the actual source of the Tonga-Fiji 
plume is still unknown. Among candidates proposed by Lupton et al. (2004), the Futuna Spreading Center (FSC) and surroundings exhibit many characteristics conducive to extensive hydrothermal activity. Moreover, the depth range of the area coincides with the predicted one by Lupton and coworkers. This area is located on the western border of the fastest tectonic area in the world at the junction of the Lau and North-Fiji basins (Figure 1). Here, the unstable back-arc accommodates the plate motion in three ways: (i) the north Fiji transform fault, (ii) numerous unstable spreading ridges, and (iii) large areas of recent volcanic activity (Pelletier, 2003; Pelletier et al., 2001). This combination of faults and widespread volcanism is particularly favourable for hydrothermal activity. Moreover, the presence of both a basaltic ridge and off-axis volcanoes opens up the possibility for a variety of fluid and mineralisation compositions to occur. Three cruises (Futuna 1, Futuna 2, Futuna 3) conducted in fall 2010, 2011 and spring 2012 were dedicated to exploration in the vicinity of the Wallis and Futuna islands located in the French EEZ. The objectives were to map the extension of recent volcanic activity, to study the tectonic framework and to locate hydrothermal discharges. Here we report on the water column survey of hydrothermal tracers (nephelometry, methane, manganese and helium isotopes) which led to the discovery of an extensive area of hydrothermal activity with a wide variety of venting. The western limit of this active zone was found to be the FSC. Four distinct hydrothermally active areas named Kulo Lasi Caldera, Amanaki, Fatu Kapa and Tasi Tulo are presented and discussed here. The present work is key piece of the puzzle of hydrothermal exploration in the SW-Pacific and shows the importance of back-arc hydrothermal activity to the ocean chemistry.

\section{Geological settings}

Wallis, Futuna, and Alofi islands are located at the transition between the North Fiji and the Lau back-arc basins. This geodynamical setting accounts for complex volcanic and 
tectonic activity in the area. Pelletier et al. (2001) and Fouquet et al. (2015a) observed multiple active extensional zones including widespread areas composed of numerous individual volcanoes (e.g. Southeast Futuna volcanic zone) and well organized spreading centers such as the Futuna and Alofi oceanic ridge (Figure 1). It has been proposed indeed that the mafic and felsic volcanic rocks present throughout the study area south-east and south-west of Futuna Island may have a triple origin (Labanieh et al., 2011). West of Futuna Island, the $20-30^{\circ}$ trending FSC is composed of a series of en echelon spreading segments. The opening rate of this oceanic ridge has been estimated at $4 \mathrm{~cm} / \mathrm{yr}$ from the interpretation of magnetic anomalies (Pelletier et al., 2001). East and south-east of Futuna Island, bathymetric maps, and reflectivity data clearly reveal that active extension and recent volcanism occurs in the Southeast Futuna volcanic zone (SEVZ) and along the Alofi spreading center. The SEVZ is a broad zone of diffuse volcanism bordered by the ENE-WSW trending volcanic graben (Named Tasi Tulo graben) to the north and the NNE-SSW trending Alofi spreading center to the south. The SEVZ includes Kulo Lasi active volcano, the Amanaki volcano, the Fatu Kapa and Tasi Tulo volcanic zones (Figure 1, Table 2).

Kulo Lasi is a shield volcano located about $100 \mathrm{~km}$ south-east of Futuna Island (Figure 2A). It represents the most recent volcano in the SEVZ and is composed of basaltic to trachyandesitic lava with no direct geochemical affinity with subduction (Fouquet et al. submitted). The volcanic edifice is ca. $20 \mathrm{~km}$ in diameter and appears relatively flat with the top located at a depth of $1200 \mathrm{~m}$ and the base only $400 \mathrm{~m}$ deeper (ca. $1600 \mathrm{~m}$ below sea level). It exhibits a central caldera ( $5 \mathrm{~km}$ in diameter and 200-300 m deep) with a flat bottom covered by recent lavas and a central mound composed of older and tectonised lava flows (Fouquet et al., submitted). The Tasi Tulo area comprises a large central volcano (10 km in diameter and called the central volcano) located near the western end of the Tasi Tulo ENE-WSW trending graben (Figure 2D). It is composed of mafic volcanic rocks locally covered by thick 
sediments. The Fatu Kapa volcanic area is in a $20 \mathrm{~km}$ wide transition zone between the Tasi Tulo graben, and the Kulo Lasi volcano. Here only small $(<1 \mathrm{~km})$ volcanic edifices are seen consisting of young mafic to felsic lavas (Figure 2C). South of the Kulo Lasi volcano the tectonic direction changes to a NNE-SSW direction. Backscattered imagery shows that recent volcanic activity occurs along the crest of the Alofi ridge and on the off-axis Amanaki (Figure 2B). Magmatic rocks are composed of basalts mainly dominated by a MORB-type signature.

\section{Methods}

To survey the water column for hydrothermal plumes, our exploration strategy made use of a network of CTD/rosette casts with a grid size of about 10 to 15 nautical miles (nmi). Yet targets for $\mathrm{CTD} /$ rosette deployments were chosen according to where high resolution bathymetry (multibeam echosounder EM122) and backscatter imagery (monobeam echosounder ER60) pointed to very likely hydrothermal discharges. Several geochemical $\left(\mathrm{CH}_{4}, \mathrm{Mn},{ }^{3} \mathrm{He}\right)$ and geophysical (nephelometry) tracers were combined to confidently identify that plumes from water column survey were hydrothermal in origin. For a given plume, some tracers may not exhibit any anomalies while some anomalies may not be of hydrothermal origin (e.g. Charlou et al., 1998). When hydrothermal anomalies were detected, additional stations were occupied to better constrain the location of the source of the plume. In parallel to this a water column survey was carried out using the echosounder (EM2040) of the AUV $\operatorname{Idef}^{\mathrm{X}}$ (e.g. Dupré et al., 2010; Kumagai et al., 2010; Dupré et al., 2015). We attempted to sample the buoyant plume four times by deploying the $\mathrm{CTD} /$ rosette at locations where water column acoustic signals of likely fluid sources were observed and correlated with topographic structures (Dupré et al., 2012; Nakamura et al., 2013).

A high precision Sea Bird 911plus CTD was equipped with a SBE3 temperature sensor, SBE4 conductivity sensor, SBE12 pressure sensor and augmented with two Seapoint 
Turbidity Meters (STM). Real-time data were transmitted via a self-supporting electro cable to an SBE 11plus V2 Deck Unit and displayed using the Seasave7 software. Data were converted and processed using the SBE Data Processing software. The Seabirdrecommended data corrections were performed. In addition, the $24 \mathrm{~Hz}$ nephelometry data were averaged every 2 seconds and outliers were then discarded using the median absolute deviation. The CTD/rosette was deployed either as vertical casts with a single round trip between the ship and $5 \mathrm{~m}$ above seafloor or as towed casts in which the instrument was lowered and raised (designated as profile $\mathrm{P} \#$ ) between a constant set depth and $5 \mathrm{~m}$ above seafloor whilst the ship moved along a set course. Each cast was designated as follows: FUxHY-yy, with $x$ the cruise number and yy the operation number. Sixteen standard 8 L Niskin bottles were mounted on the rosette for collection of discrete water column samples. They were fitted with Teflon ${ }^{\circledR}$ stopcocks and sealed with Viton ${ }^{\circledR}$ O-rings, both compatible with metal analyses. Copper tubes were filled in and sealed for onshore $\mathrm{He}$ isotopes measurements. Air tight glass ampoules were filled by gravity directly from the Niskin bottles, let overflow before closing to avoid air contamination and immediately analysed for $\mathrm{CH}_{4}$. Aliquots of water column sample were collected in $\mathrm{HDPE}$ bottles for $\mathrm{SiO}_{2}$ and total dissolved manganese (TDM) analyses. The bottles were acid prewashed for Mn analyses.

Methane was extracted by purge and trap and analyses were carried out by Gas Chromatography-Flame Ionization Detection (7890A - Agilent) within 2 hours after samples retrieval. The technique has been modified after Swinnerton et al. (1962) and is described in Charlou and collaborators (1988; 1987) (Suppl. Material).

${ }^{3} \mathrm{He}$ and ${ }^{4} \mathrm{He}$ isotope measurements were performed at the CEA-Saclay noble gas facility using a MAP 215-50 mass spectrometer (Jean-Baptiste et al., 1988; Jean-Baptiste et al., 2010; Jean-Baptiste et al., 1992). 
TDM and $\mathrm{SiO}_{2}$ were analysed by segmented flow analyses. Samples for TDM analyses were acidified (sample final $\mathrm{pH}=1.8$ ) using a $\mathrm{HNO}_{3}$ ULTREX II (J.T. Baker) solution to release all leachable $\mathrm{Mn}(\mathrm{II}+)$. The analytical technique is based on the method developed by Stickland and Parsons (1968) (Suppl. Material).

$\mathrm{SiO}_{2}$ was measured in each rosette sample and the value was compared to a reference profile of the area in order to identify Niskin bottles that would not have closed at the set depth value. Silicate ions were quantified by colorimetry at $660 \mathrm{~nm}$ using heptamolybdate ammonium (Sigma-Aldrich) on an auto-analyser II from Bran and Luebbe (SPX corp., USA) equipped with a numerical colorimeter. The analytical technique is based on the method described by Mullin and Riley (1955) and adapted for automatic analyses after Grasshoff (1970) (Suppl. Material).

\section{Results and discussion}

In total, 157 CTD casts (of which 105 had associated water samples) were carried out during the Futuna 1, 2 and 3 cruises in 2010, 2011 and 2012. Our exploration strategy enabled us to discover 4 distinct hydrothermally active areas within the volcanic zone East and SE of Futuna Island: namely Kulo Lasi, Amanaki, Fatu Kapa and Tasi Tulo. No hydrothermal activity could be found on the Futuna Ridge and in the recent volcanic areas, West and NW of Futuna Island (Figure 1).

Our survey showed that the entire active region was characterised by wide-spread hydrothermal activity exhibiting a complex distribution of tracers in the water column. Although $\mathrm{CH}_{4}, \mathrm{Mn},{ }^{3} \mathrm{He}$ and nephelometry generally correlated with each other, some discrepancies between these tracers were observed. Such observations are typical of the SW Pacific Ocean where plumes have usually been reported to display more variability than their 
MOR homologues (e.g. Baker et al., 2011; Lisitzin et al., 1997; Resing et al., 2011). Indeed, in the SW Pacific, geodynamic settings, magmatism, multiple type seismicity (subduction, hot spot, faults (Pelletier et al., 2000) and the composition of igneous rocks in Back-Arc Basins (BABs) are factors complicating and influencing the distribution and composition of hydrothermal plumes. For instance bottom anomalies and vertical decoupling of the tracers are common in BABs (Lisitzin et al., 1997).

\subsection{Background concentrations}

The dataset corresponding to $\mathrm{CTD} /$ rosette operations that did not reveal any anomalies on multiple tracers was compiled to obtain background vertical profiles (Figure 1, Figure 3). The survey revealed the presence of chronic plumes of ${ }^{3} \mathrm{He}$ and TDM while $\mathrm{CH}_{4}$ showed usual deep ocean background values.

\subsubsection{Manganese}

Although background values can be highly variable over the oceans the studied area was undeniably enriched in $\mathrm{Mn}$ (3-5 nM) compared to all three Pacific (0.1-0.8 nM range (Klinkhammer and Bender, 1980; Resing et al., 2015; Wu et al., 2014)), Atlantic (0.25 nM (Klinkhammer et al., 1985) and Indian Oceans (0.17-0.37 nM range (Kawagucci et al., 2008; Geotraces Intermediate Data Product, 2014)) (Figure 3B). It was still higher than the elevated regional TDM background in the SW Pacific (0.7-1.1 nM (German et al., 2006; Lisitzin et al., 1997)). Considering the numerous indications of high-T hydrothermal activity, low-T diffuse venting and recent volcanism observed in the area, both cumulative hydrothermal venting and volcanic discharges are likely good candidates to explain this chronic manganese input to the Wallis and Futuna region. This excess TDM in the water column was also observed in the rocks with an anomalous number of Mn crusts and deposits on the seafloor in the study area (Pelleter et al., 2015; Pelleter et al., submitted). 


\subsubsection{Helium}

The ${ }^{3} \mathrm{He}$ background $(25-45 \%)$ in the Wallis and Futuna region far exceeded typical background values for the West Pacific $(<25 \%)$ and was similar to what was observed by Lupton et al. (2012) in the nearby northwest Lau Basin and at station 263 of the GEOSECS expedition (Figure 3C). Elevated background values at $2500 \mathrm{~m}$ depth are likely due the distal influence of the East Pacific Rise (EPR) plume (Lupton et al., 2004) while at $2100 \mathrm{~m}$ they may be attributed to the recently discovered and nearby Central Caldera plume (Lupton et al., 2012) (Figure 1). The extensive Tonga-Fiji hydrothermal plume is also visible on our profiles with $\delta^{3} \mathrm{He}$ value up to $45 \%$ between 1350 and $1700 \mathrm{~m}$ depth comparable to what was reported at station TEW 46 just south of the Futuna Ridge (Lupton et al., 2004). We discuss this ${ }^{3} \mathrm{He}$ regional plume in $\S 4.5$.

\subsubsection{Methane}

No such methane above the regional background was observed probably because the lessconservative behaviour of $\mathrm{CH}_{4}$ in the water column. Methane oxidation rate is much faster than the scavenging rate of $\mathrm{Mn}$ resulting in a residence time of days for $\mathrm{CH}_{4}$ vs months for Mn in the water column (e.g. Cowen et al., 1990; de Angelis et al., 1993; Kadko et al., 1990; Lavelle et al., 1992). The local background level of $\mathrm{CH}_{4}$ in the water column ranged between 0.2-0.5 $\mathrm{nM}$ of $\mathrm{CH}_{4}$ which is in good agreement with values reported for the Pacific $(\sim 0.2 \mathrm{nM})$ and Atlantic Oceans ( 0.4 nM) (e.g. Charlou and Donval, 1993; Charlou et al., 1991) (Figure $3 \mathrm{~A})$.

\subsection{Kulo Lasi Caldera}

The Kulo Lasi plume was discovered in 2010 during the Futuna 1 cruise and the area was revisited in 2011 (Futuna 2 cruise). A reasonable coverage of the caldera and its close 
vicinity was obtained through $10 \mathrm{CTD} /$ rosettes operations and one NW-SE Tow-Yo (Figure 2A). The plume was characterised by strong and consistent anomalies of nephelometry, $\mathrm{CH}_{4}$, TDM and $\delta^{3} \mathrm{He}$. In 2010 (Futuna 1$) \delta^{3} \mathrm{He}(\max 109 \%$ ) was about 3 times the background value, TDM ( $\max 76.4 \mathrm{nM}$ ) was up to 20 times more concentrated than in surrounding waters while $\mathrm{CH}_{4}(\max 50.5 \mathrm{nM})$ reached concentrations more than 2 orders of magnitude higher than the local background concentrations (Figure 3). When the site was revisited in 2011 during Futuna 2, $\mathrm{CH}_{4}$ levels had dropped dramatically by a factor of 10, whilst TDM and ${ }^{3} \mathrm{He} /{ }^{4} \mathrm{He}$ ratio appeared relatively stable (Figure 4 station FU2-HY-20). The survey results display substantial differences in profiles of different tracers at Kulo Lasi (Figure 4). Water column anomalies are usually chaotic in calderas because of their geometry, associated local currents and their relative confinement (e.g. Resing et al., 2009; Staudigel et al., 2004; You et al., 2014). However, our results suggest the presence of several vents, possibly having different chemistries, on the floor and on the walls of the caldera.

\subsubsection{Types and distribution of vents}

In a weakly stratified ocean, symmetrical plume shapes observed well above seafloor are usually diagnostic of high-T black smoker-type venting whereas anomalies closer to the bottom are diagnostic of low-T diffusive venting. Plume rise heights are the result of differential stratification best defined by temperature (T), salinity (S) and density $(\rho)$ in the water column (Staudigel et al., 2004). CTD profiles inside the caldera show that the water mass was stratified (Suppl. Material Figure S1), suggesting that the observed variability in the vertical and horizontal tracer concentrations is related to both high- (e.g. FU1-HY-34, 40 and 41) and low-T (e.g. FU1-HY-33, FU1-HY-40 and FU2-HY-20) venting within the caldera (Figure 2A, Figure 4). 
Besides, we observed a plume depth difference (more than $100 \mathrm{~m}$ ) between stations located inside vs. outside the caldera (Figure 4). Since the hydrothermal plumes from adjacent active areas (Amanaki $\S 4.3$ and Fatu Kapa $§ 4.4$ ) are deeper, the tracer anomaly seen outside of the caldera must originate from the Kulo Lasi volcano itself (Figure 3). However, the symmetrical shape of the plume especially observed at station FU1-HY-38 does not match that corresponding to a simple overflow above the caldera rim (Figure 4). Most probably, this anomaly was created by additional high temperature venting located on the caldera walls. Consistent with this, the high resolution nephelometry dataset indicated venting from the SE wall, as well as above the central cone, and also on the caldera floor (Figure 5).

In 2010 (Futuna 1), the highest $\mathrm{CH}_{4}$ and nephelometry values were recorded at station FU1-HY-34 and FU1-HY-40 in the south half of the caldera whereas TDM was at a maximum at station FU1-HY-33 and FU1-HY-34 in the center (Figure 2A). In 2011, nephelometry was generally higher along the south-eastern section of this transect. Associated profiles of the other tracers are unfortunately not available in this Tow-Yo mode. Yet discrete samples were collected at 2 constant depths, outside $(1160 \mathrm{~m})$ and inside $(1310$ m) the caldera respectively, where maximum concentrations were expected. Although these particular values may not represent absolute maxima, it seemed that a more intense activity was present in the south-east of the caldera in 2011 (Table 3). Once again this argues towards the presence of multiple vents scattered all over the caldera.

At station FU1-HY-33 located at the base of the central volcanic cone, tracers exhibited a peculiar behaviour (Figure 4): there, helium, manganese and nephelometry showed a maximum at $\sim 1200 \mathrm{~m}$ and high concentrations were maintained down to $15 \mathrm{~m}$ above the seafloor. These vertical distributions are quite typical of calderas and are likely the result of low-T diffuse flows (Resing et al., 2009; Staudigel et al., 2004). By contrast methane continuously increased from $1100 \mathrm{~m}$ down to the caldera floor. Methanogens thriving at 
seafloor diffuse vents is not a likely explanation for the decoupling between methane and other tracers since they can hardly sustain the continuous increase of $\mathrm{CH}_{4}$ with depth, and do not account for the other tracers found in the large anomaly $300 \mathrm{~m}$ above seafloor (Love et al., 2008). The possible origin of this large $\mathrm{CH}_{4}$ flux at the bottom of the caldera is discussed below.

\subsubsection{Possible origins of the $\mathrm{CH}_{4}$ transcient source}

$\mathrm{CH}_{4} /{ }^{3} \mathrm{He}$ and $\mathrm{CH}_{4} / \mathrm{TDM}$ ratios in 2010 (Futuna 1) showed two different trends (Figure 6): deep waters $(>1300 \mathrm{~m})$ had much higher tracer ratios than shallow waters $(<1200 \mathrm{~m})$. On the contrary, 2011 results (Futuna 2) define a unique trend with much lower ratios. This double trend and the drastic change between 2010 and 2011 are not apparent in the TDM- ${ }^{3} \mathrm{He}$ plot (Figure 6), indicating that a transient $\mathrm{CH}_{4}$ source was present at Kulo Lasi in 2010 or earlier and had vanished in 2011.

Excess methane observed at Kulo Lasi in 2010 was likely associated with a magmatic event. The elevated $\mathrm{CH}_{4} /{ }^{3} \mathrm{He}$ and $\mathrm{CH}_{4} / \mathrm{TDM}$ observed in 2010 are the highest values seen during the three cruises and as high as values reported in mega plumes (Gamo et al., 1993; Love et al., 2008; McLaughlin et al., 1999; Mottl et al., 1995). Magmatic events can produce such high ratios due to the release of large amounts of $\mathrm{H}_{2}$ and $\mathrm{CO}_{2}$ and subsequent formation of $\mathrm{CH}_{4}$ (Butterfield et al., 1997; Lupton et al., 1993). Hydrogen may originate from: (1) seawater reacting with extremely hot rock at cracking fronts associated with dike injection (Butterfield et al., 1997); (2) seawater / lava interaction (Sansone et al., 1991); (3) oxidation of iron to magnetite with a corresponding reduction of $\mathrm{H}_{2} \mathrm{O}$ to $\mathrm{H}_{2}$ in water-rich magma. Carbon dioxide is usually directly released from the magma (e.g. Javoy and Pineau, 1991; Soule et al., 2012) but could also be derived from a thermogenic degradation of organic matter present on the seafloor or in the subsurface when lava is flowing (Haymon et al., 
1993). It is probable that in the context of Kulo Lasi, $\mathrm{CO}_{2}$ and $\mathrm{H}_{2}$ have mixed origins. Subsequent generation of high amounts of $\mathrm{CH}_{4}$ could then be the result of: (1) the abiotic reduction of $\mathrm{CO}_{2}$ by $\mathrm{H}_{2}$ (McCollom and Seewald, 2007; McCollom, 2013 and references therein); (2) intense methanogenesis associated with a microbial bloom due to elevated concentrations of substrates $\left(\mathrm{CO}_{2}\right.$ and $\left.\mathrm{H}_{2}\right)$ (Holden et al., 1998; Meyer et al., 2013) and warm temperatures (McCollom and Seewald, 2007; Summit and Baross, 1998); (3) a combination of both. A fourth possibility is that lava flowing over the seafloor results in the release of subsurface biogenic methane (Takai et al., 2004). In such magmatic rapid processes ${ }^{3} \mathrm{He}$ and Mn would not have time to be leached from the rocks and would thus keep low concentrations with respect to $\mathrm{CH}_{4}$.

High $\mathrm{CH}_{4} /{ }^{3} \mathrm{He}$ and $\mathrm{CH}_{4} / \mathrm{TDM}$ ratios have also been reported in chronic plumes at sedimented settings or in ultramafic contexts at unsedimented ridges with the exception of the Endeavour segment on the Juan de Fuca ridge and the Dodo Great Lava Plain on the Central Indian Ridge (Table 1). A large amount of biogenic and/or thermogenic $\mathrm{CH}_{4}$ is leached from the thick layer of sediments in the first case (e.g. Cruse and Seewald, 2006; Simoneit et al., 1988; Welhan and Lupton, 1987); serpentinisation of mantle rocks is responsible for the high ratios found at unsedimented ridges (e.g. Charlou et al., 1998); sediments buried at an early stage of the Juan de Fuca ridge's formation have been proposed for the elevated $\mathrm{CH}_{4}$ concentrations measured there (Cruse and Seewald, 2010; Lilley et al., 1993); while the origin is unclear at Dodo (Kawagucci et al., 2008). These hypotheses are unlikely to apply to our study area where burial of ancient organic matter would be inconsistent with the young volcanic context and no large sedimented zones or serpentinites were observed.

Additional evidence of a recent eruption prior to our visit in 2010 is excess nephels compared to other tracers at Kulo Lasi. Although there are some exceptions, strong positive deviation of nephel vs other tracers has often been observed during or after eruption (e.g. 
Feely et al., 1999; Feely et al., 1994; Resing et al., 2009; Resing et al., 2011). Elemental sulphur released during eruption enhances the backscattering efficiency of turbidity meters compared to Fe-Oxyhydroxides particles found in chronic plumes (Baker et al., 2001). The volcanic eruption hypothesis, which is also strongly supported by the presence of fresh lavas, is thus very likely the best candidate to explain methane behaviour.

\subsection{Amanaki area}

The Amanaki plume signal was first detected in 2010 but most of the sampling was done during the Futuna 2 cruise in 2011. Altogether 12 CTD/rosette and one Tow-Yo operations were carried out on the Amanaki area (Figure 2B). Clear and consistent anomalies in nephelometry, $\mathrm{CH}_{4}, \mathrm{TDM}$, and $\delta^{3} \mathrm{He}$ were recorded between 1650 and $2150 \mathrm{~m}$ depth with the plume being $500 \mathrm{~m}$ thick and centred at $1900 \mathrm{~m}$ depth (Figure 7). The distribution of the tracers was strikingly alike at all stations.

\subsubsection{Origin of the plume}

An American / Australian cruise conducted in 2008 discovered 3 active calderas south $(\sim 25 \mathrm{~km})$ and north-east $(\sim 110 \mathrm{~km})$ of Amanaki: the Southern Caldera, Central Caldera and Lobster Caldera visible in Figure 1 (Lupton et al., 2012). However, an influence of these vents in the Amanaki area is unlikely primarily because the prevalent currents at $1500-2000$ $\mathrm{m}$ water depth in the area are north-westward to northward (Reid, 1986, 1997; Speer and Thurnherr, 2012). If we would have detected the Southern and Central Caldera plumes then the anomalies should have logically been greater at our southernmost stations FU1-HY-22, FU1-HY-25 and FU2-HY-27 (Figure 2B). Moreover, the diffuse venting reported for the Southern Caldera is unlikely to produce a detectable plume as far as our stations. Additionally, Lobster Caldera plume is at $1400-1500 \mathrm{~m}$ depth and had a ${ }^{3} \mathrm{He} /{ }^{4} \mathrm{He}$ ratio of 19 
Ra which is significantly different than the $1900 \mathrm{~m}$ depth and the 9 Ra that we observed (Table 2). This strongly indicates that the Amanaki's plumes must be due to venting sources in the area.

Because the largest anomalies were initially observed at station FU2-HY-29, a $5 \mathrm{~km}$ long SW-NE Tow-Yo was performed over that station and an additional 8 water samples were taken along at $1900 \pm 25 \mathrm{~m}$ depth (FU2-HY-33-Tow-Yo in Figure 2B). Analysis of the entire Amanaki dataset indicates maximum tracer concentrations at stations FU2-HY-29, FU2-HY34 and on the northern end of the transect FU2-HY-33 Tow-Yo (Figure 7, Table 3). All other stations deployed in a $\sim 8 \mathrm{~km}$-radius circle have lower concentrations (Figure 2B). These observations combined with the fact that TDM concentration decreases rapidly in the water column with increasing distance to the source strongly indicates the presence of the source within a few 100 meters of stations FU2-HY-29 and FU2-HY-34, at the northern end of the Alofi ridge (Lavelle et al., 1992).

\subsubsection{Type of venting}

The vertical distribution of the tracers at Amanaki resembled the classical ones recorded at MOR where there is usually one clear maxima coinciding for all tracers located well above the sea-floor. Such profiles are usually associated with focused flow and spatially constrained high-T black smoker-type hydrothermal fields. Tracer ratios $\left(\mathrm{CH}_{4} / \mathrm{TDM}=0.1 ; \mathrm{CH}_{4}{ }^{3} \mathrm{He}=\right.$ $\left.2 \times 10^{6} ; \mathrm{TDM} /{ }^{3} \mathrm{He}=27 \times 10^{6}\right)$ are typical of MOR mafic hydrothermal fields and seawaterbasalts interactions (Suppl. Material Figure S2) (Charlou and Donval, 1993; Charlou et al., 1996; Jean-Baptiste et al., 1991; Welhan and Craig, 1983). ${ }^{3} \mathrm{He} /{ }^{4} \mathrm{He}$ (9 Ra) of the plume also falls in the upper range of typical MORB (7-9 Ra). That is consistent with the location of Amanaki on the flank of the Alofi active ridge and the MORB type basalts which are the 
dominant lavas in the area. All this strongly supports the presence of basalt-hosted hydrothermal activity in the Amanaki region.

\subsection{Fatu Kapa and Tasi Tulo regions}

The area was surveyed and studied using 27 CTD/rosette casts and one Tow-Yo in 2011 (Futuna 2) and 2012 (Futuna 3) (Figure 2C\&D, Figure 8 and Figure 9). Although hydrothermal plumes in the area were found in the same range of depth $(\sim 1400-1550 \mathrm{~m})$ and showed similar medium anomalies in $\mathrm{CH}_{4}$, TDM and $\delta^{3} \mathrm{He}$, the difference in nephelometry indicated the presence of two distinct plumes which resulted in studying the two zones separately: Fatu Kapa, distinguishable by a weak but clear nephelometric anomaly, and Tasi Tulo not showing any turbidity. Generally, a good correlation between tracers was obtained but a great diversity of profiles was observed in both zones (Figure 8, Figure 9). A $3 \mathrm{~km}$ long Tow-Yo transect (FU3-HY-05 Tow-Yo) performed in northern Fatu Kapa supports the apparent complexity of the plumes geochemistry and geometry. Along the profile and at depth ranging from 1465 to $1525 \mathrm{~m}$, great (up to 1 order of magnitude) sawtooth covariation of the tracers was observed (Table 3). A slight increase in all the tracer values was also detected towards the northern end of the section.

\subsubsection{Unusual distribution of vents at Fatu Kapa}

The geochemical and geophysical survey implied the entire $130 \mathrm{~km}^{2}$ area was under hydrothermal influence. Each station showed anomalies with varied tracer distributions in the water column likely suggesting inputs of numerous hydrothermal vents (Jean-Baptiste et al., 2004). However, we note that differences between profiles can also be due to topography and density stratification (e.g. Carazzo et al., 2013; Ernst et al., 2000; Ernst et al., 1994; German et al., 1998; Xu and Di Iorio, 2012). Nevertheless, we recognised at least three individual 
plumes in the Fatu Kapa area at 1150-1250 m, 1400-1480 m and 1500-1580 m (Figure 8). We attribute the upper anomaly to the Kulo Lasi plume based on consistent depth and increasing signal at stations closer to Kulo Lasi and the two deep plumes to the combined contribution of multiple fields on the seafloor (Figure 8). The distribution of hydrothermal fields over such a large area is very unusual and has not, to our knowledge, been reported. To that respect, while hydrothermal discharge is generally best described by point (hot spots) or line (MOR, arc volcanoes) sources, the Fatu Kapa area is best described by a diffuse areal distribution.

\subsubsection{Diversity of venting at Fatu Kapa}

First of all analysis of the profiles of the non-buoyant plumes strongly suggest the presence of both high-T venting and widespread low-T diffuse venting (Figure 8). Unravelling the origin of the different non-buoyant plumes at Fatu Kapa cannot be made on the basis of the geochemical tracer ratios. While there are slight differences in the $\mathrm{CH}_{4} / \mathrm{TDM}$ at Fatu Kapa our entire dataset yields a ratio of 0.29 (Table 1, Suppl. Material Figure S3). $\mathrm{CH}_{4} / \mathrm{TDM}$ values ranging between 0.1 and 1 are associated with sites along the MOR system over the world and independently of the spreading rate, in BABs (Manus, North Fiji, Lau), along volcanic arcs, and at hot spots. Consequently such ratios are not diagnostic and may represent "typical" venting, in which the $\mathrm{CH}_{4}$ originates from magmatic degassing, bacterial production, reaction between seawater and basalt, or some combination of these processes (Mottl et al., 1995; Welhan, 1988). Because the helium data set in this region is very limited (only collected in 2011) the relationship of helium with methane and manganese were treated using all of the data collected in the Fatu Kapa and Tasi Tulo regions (Table 1). The values we obtained are also consistent with BABs and/or volcanic arc context (Table 1). 
On the other side, a selection of locations, where acoustic signals of probable fluid sources were observed, was made to deploy the CTD/rosette with the hope of sampling the buoyant plume or at least a single fluid source-plume. These targets were named Stéphanie (FU3-HY06), $\operatorname{Idef}^{\mathrm{X}}(\mathrm{FU} 3-\mathrm{HY}-16)$, Obel $^{\mathrm{X}}(\mathrm{FU} 3-\mathrm{HY}-18)$ and Fati Ufu (FU3-HY-23) (Figure 2C). The much higher $\mathrm{CH}_{4}$ and TDM concentrations in these samples as well as the study of the TS diagrams suggest the operations were successful in getting closer to the hydrothermal sources (Suppl. Material Figure S4 and S5). Differences in the $\mathrm{CH}_{4} / \mathrm{TDM}$ ratios and in nephelometry point to at least 3 different fluid sources (Table 1). The variations of $\mathrm{CH}_{4} / \mathrm{TDM}$ seemed to be due to changes in $\mathrm{CH}_{4}$ concentration with a homogeneous TDM distribution over the Fatu Kapa area (Table 1). As discussed previously, hydrothermal sources of $\mathrm{CH}_{4}$ released by deep-sea hydrothermal systems are multiple: (1) thermal breakdown of complex hydrocarbons at temperatures higher than $100{ }^{\circ} \mathrm{C}$; (2) biological production; (3) outgassing of juvenile carbon as $\mathrm{CH}_{4}$ from the mantle either by direct gas loss at the magmatic stage or by rock leaching as fluids circulate; (4) abiotic synthesis under high pressure and temperature (Welhan, 1988). (1) implies a significant supply of sediments, which we know are almost non-existent in the study area. (3) and (4) require high-T fluid circulation in mantle rocks which can be ruled out in the geological context of the present study. However, magmatic gass (3) may be considered as an option because the $\mathrm{CH}_{4} /{ }^{3} \mathrm{He}$ ratio of the Fatu Kapa plumes was consistent with the MORB glass range $\left(0.7-2.5 \times 10^{6}\right)$ (Welhan and Craig, 1983). Biogenic methane (2) should also be fully considered because Fatu Kapa very likely hosts numerous diffusion zones which constitute favourable environments for microorganisms to grow most notably methanogens (Nercessian et al., 2005; Ver Eecke et al., 2012).

Only Fati Ufu showed a nephelometric anomaly. The absence of nephelometry at Stephanie, $\operatorname{Idef}^{\mathrm{X}}$ and $\mathrm{Obel}^{\mathrm{X}}$ may be due to lack of either $\mathrm{H}_{2} \mathrm{~S}$ or metal to form the sulphur or Feoxyhydroxides particles responsible for turbidity. Phase separation and the subsequent 
venting of the vapour phase (metal poor) is likely the best explanation to the occurrence of non-turbid fluids (e.g. Ishibashi et al., 1994).

\subsubsection{Particle free venting at Tasi Tulo}

Anomalies of $\mathrm{CH}_{4}, \mathrm{TDM}$ and $\delta^{3} \mathrm{He}$ were similar, although slightly lower than at Fatu Kapa while $\mathrm{CH}_{4}$ vs TDM in the Tasi Tulo plume plotted along the same line as Fatu Kapa (Table 1). Yet the absence of turbidity was characteristic in the Tasi Tulo area both in 2011 and 2012 and strongly argues for the presence of a distinct source that remains to be discovered (Figure 2D, Figure 9). Yet based on the absence of nephelometry one can expect that similar types of venting as Stephanie, $\operatorname{Idef}^{\mathrm{X}}$ and $\mathrm{Obel}^{\mathrm{X}}$ might be the dominant style of venting at Tasi Tulo. The location of this plume at the intersection between the central volcano and the Tasi Tulo graben faults is also very favourable to drive significant hydrothermal activity combining both a local heat source and faults.

\subsubsection{Temporal variability at Fatu Kapa and Tasi Tulo}

CTD/rosette deployments made at the exact same location in 2011 and 2012 clearly showed stability of the tracers concentrations over time but significant depth variations (100$150 \mathrm{~m}$ ) (Figure 8, Figure 9 and Table 4). This suggests that hydrothermal activity is persistent in the area but that either temporal variability of the strength of hydrothermal activity or small changes in current speed and direction (e.g. tidal effect) have substantially altered the height of the plumes (Gamo et al., 1993; German et al., 2006; Jean-Baptiste et al., 1998; Rudnicki and German, 2002; Rudnicki et al., 1994). 


\subsection{Implications for the Tonga-Fiji plume}

Lupton et al. postulated that the source of the extensive Tonga-Fiji hydrothermal plume was somewhere near the Samoa Islands or at the northern end of the Kermadec Arc - Lau Basin area and somewhere between 1450 and $1950 \mathrm{~m}$ depth. They investigated several structures that occurred to be either inactive (Macchias seamounts) or too shalow (Vailulu, arc volcanoes). The Lau Basin ${ }^{3} \mathrm{He}$ signal was assumed too weak and too distant to have produced the $\delta^{3} \mathrm{He}$ observed. Remaining candidates were the NWLSC, the FSC and the Mangatolu Triple Junction. We here show that the FSC is not active. However, the intense and widespread hydrothermal activity discovered in the West of the FSC deserves consideration as the source (or one of several sources) of this regional plume. In addition to our findings, the recently discovered Lobster, Central and Southern Calderas indicate that the active zone contributing to the Tonga-Fiji plume is even wider than our study area and extends to the East (Lupton et al., 2012). While additional hydrothermal activity near the Samoa Islands is also likely, we do not believe that it is solely responsible for the extensive plume observe in the region. Also, the depths of the hydrothermal sources that we discuss here are more compatible with the plume height of the regional ${ }^{3} \mathrm{He}$ plume. We propose that the center of the plume illustrated in fig 5 in Lupton et al. (2004) could be shifted to the West and thus the $\delta^{3} \mathrm{He}$ isocontours would appear more concentric. This regional view emphasizes the considerable hydrothermal input to the ocean of the whole domain including Kulo Lasi, Lobster, Central and Southern Calderas as well as Amanaki, Tasi Tulo and Fatu Kapa areas.

\section{Concluding remarks and summary}

Our study area is characterised by an intense and widespread hydrothermal activity, as evidenced by the number and variety of tracer anomalies, as well as by the high ${ }^{3} \mathrm{He}$ and $\mathrm{Mn}$ background which point to a chronic hydrothermal input over the entire area. The area was 
also characterized by the complexity of the distribution of the tracers in the water column: we often observe a substantial spatial heterogeneity in the shape of the plumes recorded by the various hydrothermal tracers at different stations of the same area, as well as a strong temporal variability. We associate these variations to the presence of multiple venting sites of different geochemistry, as well as to the complexity of the geodynamics and the variability with deep currents. To summarise, our study area is best described by $2 \mathrm{D}$-distribution of the activity rather than usual $1 \mathrm{D}$ (point or line source). As far as our knowledge this has never been observed in the Pacific were most hydrothermal fields are controlled by back arc ridges or individual volcanoes of the submerged arc. We attribute this to the intense tectonic and volcanic activity creating a huge active domain where numerous heat sources and faults are able to drive widespread hydrothermal systems.

It is also worth pointing out the remarkable diversity of hydrothermal activity found in our relatively constrained study area, including focused and diffuse fluid flow of both high-T and low-T. Different geochemistries of the plumes were also observed and are most probably the result of hydrothermal activity related to all four volcanic (Kulo Lasi), ridge (Amanaki), graben (Tasi Tulo) and diffuse volcanic activity (Fatu Kapa). Notably, our data and especially $\mathrm{CH}_{4} / \mathrm{TDM}$ and $\mathrm{CH}_{4} /{ }^{3} \mathrm{He}$ ratios at Kulo Lasi reveal a transient $\mathrm{CH}_{4}$ input most likely caused by an eruptive magmatic event.

This very first hydrothermal exploration of the Wallis and Futuna region did not reveal any activity on the FSC that is proposed to set the western boundary of the hydrothermally active region which extends over an area of about $150 \times 175 \mathrm{~km}$. It includes the Kulo Lasi Caldera, Amanaki volcano, Fatu Kapa and Tasi Tulo areas on the French side (this study) and the Lobster, Central and Southern Calderas on the Tongan side (Lupton et al., 2012). We believe 
the contribution of this large domain to the regional ocean chemistry is significant and in particular to the extensive Tonga-Fiji plume as shown by the ${ }^{3} \mathrm{He}$ data.

Altogether our results support the idea that back-arc regions may contribute to a great part to the global hydrothermal heat and geochemical input to the ocean as suggested by Hawkes et al. (2015). Also, since hydrothermal plumes constitute the vectors for elements, larval dispersal and nurture microbiological communities, our discovery opens up the question of the impact of back-arc systems on biogeochemical cycles (e.g. Beaulieu et al., 2011; Bennett et al., 2013; Bennett et al., 2011; Carazzo et al., 2013; German et al., 2010; Jean-Baptiste et al., 1998; Kim et al., 1994; McCollom, 2000). Therefore systematic survey and exploration of the region should go on with high resolution (e.g. C isotopes) plume survey, as well as submersible dives to collect and analyse hydrothermal fluids. These additional data will also aim at discussing more in depth some of the topics that have only been approached in the present paper devoted to the general presentation of the area. Indeed the regional ${ }^{3} \mathrm{He}$ plume, the $\mathrm{CH}_{4}$ behaviour at Kulo Lasi, the extension limits of the hot diffuse venting at Fatu Kapa and the heat / mass fluxes are fascinating subjects that deserve special attention.

\section{Aknowledgements}

The authors are grateful to Eramet, Technip and Areva for funding of the cruises. Many thanks to the ship crew; and the ship captains JR Glehen, P Moimeaux and R Picard; for running theses three cruises with skills and professionalism. We are also rewarding to D Pierre, C Guerin, A Normand for processing bathymetric data on board as well as C Scalabrin and S Dupré for processing and interpreting acoustic data. We thank our microbiologist colleagues (MA Cambon and E Roussel), geochemists colleagues (C Cathalot, C Boulart) and geologist colleague (F Besson) for their useful comments and discussions. We are indebted to 
the physical oceanographers L Marié and B Le Cann who helped a lot with fluxes estimations and water mass physics. This JISAO \#2648 and PMEL \#xxxx publication number.

\section{References}

Aballéa, M., Radford-Knoery, J., Appriou, P., Bougault, H., Charlou, J.L., Donval, J.P., Etoubleau, J., Fouquet, Y., German, C.R., Miranda, M., 1998. Manganese distribution in the water column near the Azores Triple Junction along the Mid-Atlantic Ridge and in the Azores domain. Deep Sea Research Part I: Oceanographic Research Papers 45 (8), 1319-1338.

Arculus, R. J., 2008, Voyage Summary SS07/2008 Northern Lau Vents Expedition. [http://www.marine.csiro.au/nationalfacility/voyagedocs/2008/MNF-SS07-08_sum.pdf.]

Auzende, J.M., Rissen, J.P., Lafoy, Y., Gente, P., Charlou, J.L., 1988. Seafloor spreading in the North Fiji Basin (Southwest Pacific). Tectonophysics 146 (1-4), 317-352.

Auzende, J.M., Urabe, T., Deplus, C., Eissen, J.P., Grimaud, D., Huchon, P., Ishibashi, J., Yoshima, M., Lagabrielle, Y., Mevel, C., Naka, J., Ruellan, E., Tanaka, T., Tanahashi, M., 1989. Le cadre geologique d'un site hydrothermal actif: la Campagne STARMER $1 \mathrm{du}$ submersible Nautile dans le Bassin Nord-Fid jien. Comptes Rendus de l'Académie des Sciences - Series II 309, 1787-1795.

Baker, E.T., Edmonds, H.N., Michael, P.J., Bach, W., Dick, H.J.B., Snow, J.E., Walker, S.L., Banerjee, N.R., Langmuir, C.H., 2004. Hydrothermal venting in magma deserts: The ultraslow-spreading Gakkel and Southwest Indian Ridges. Geochem. Geophys. Geosyst. 5 (8), Q08002.

Baker, E.T., German, C.R., Elderfield, H., 1995. Hydrothermal Plumes Over SpreadingCenter Axes: Global Distributions and Geological Inferences. In: Humphris, S.E., Zierenberg, R.A.M., L. S. Thomson, R. E. (Eds.), Seafloor Hydrothermal Systems: Physical, Chemical, Biological, and Geological Interactions. American Geophysical Union, pp. 47-71.

Baker, E.T., Haymon, R.M., Resing, J.A., White, S.M., Walker, S.L., Macdonald, K.C., Nakamura, K.-i., 2008. High-resolution surveys along the hot spot-affected Galápagos Spreading Center: 1. Distribution of hydrothermal activity. Geochem. Geophys. Geosyst. 9 (9), Q09003.

Baker, E.T., Lupton, J.E., Resing, J.A., Baumberger, T., Lilley, M.D., Walker, S.L., Rubin, K.H., 2011. Unique event plumes from a 2008 eruption on the Northeast Lau Spreading Center. Geochem. Geophys. Geosyst. 12, Q0AF02.

Baker, E.T., Massoth, G.J., Nakamura, K., Embley, R.W., de Ronde, C.E.J., Arculus, R.J., 2005. Hydrothermal activity on near-arc sections of back-arc ridges: Results from the Mariana Trough and Lau Basin. GEOCHEMISTRY GEOPHYSICS GEOSYSTEMS 6, Q09001.

Baker, E.T., Resing, J.A., Walker, S.L., Martinez, F., Taylor, B., Nakamura, K., 2006. Abundant hydrothermal venting along melt-rich and melt-free ridge segments in the Lau back-arc basin. Geophysical Research Letters 33 (7).

Baker, E.T., Tennant, D.A., Feely, R.A., Lebon, G.T., Walker, S.L., 2001. Field and laboratory studies on the effect of particle size and composition on optical backscattering measurements in hydrothermal plumes. Deep Sea Research Part I: Oceanographic Research Papers 48 (2), 593-604. 
Beaulieu, S.E., Mills, S., Mullineaux, L., Watanabe, H., Pradillon, F., Kojima, S., 2011. International study of larval dispersal and population connectivity at hydrothermal vents in the U.S. Marianas Trench Marine National Monument. OCEANS 2011, pp. 1-6.

Bendel, V., Fouquet, Y., Auzende, J.-M., Lagabrielle, Y., Grimaud, D., Urabe, T., 1993. The White Lady hydrothermal field, North Fiji back-arc basin, Southwest Pacific. Economic Geology 88 (8), 2237-2245.

Bennett, S.A., Coleman, M., Huber, J.A., Reddington, E., Kinsey, J.C., McIntyre, C., Seewald, J.S., German, C.R., 2013. Trophic regions of a hydrothermal plume dispersing away from an ultramafic-hosted vent-system: Von Damm vent-site, Mid-Cayman Rise. Geochemistry, Geophysics, Geosystems 14 (2), 317-327.

Bennett, S.A., Statham, P.J., Green, D.R.H., Le Bris, N., McDermott, J., Prado, F., Rouxel, O.J., Von Damm, K., German, C.R., 2011. Dissolved and particulate organic carbon in hydrothermal plumes from the East Pacific Rise, 9 $50^{\prime} \mathrm{N}$. Deep Sea Research Part I: Oceanographic Research Papers 58, 922-931.

Bertine, K.K., Keene, J.B., 1975. Submarine Barite-Opal Rocks of Hydrothermal Origin. Science 188 (4184), 150-152.

Bézos, A., Escrig, S., Langmuir, C.H., Michael, P.J., Asimow, P.D., 2009. Origins of chemical diversity of back-arc basin basalts: A segment-scale study of the Eastern Lau Spreading Center. Journal of Geophysical Research: Solid Earth 114 (B6), n/a-n/a.

Binns, R.A., Scott, S.D., 1993. Actively forming polymetallic sulfide deposits associated with felsic volcanic rocks in the eastern Manus back-arc basin, Papua New Guinea. Economic Geology 88 (8), 2226-2236.

Bischoff, J.L., Rosenbauer, R.J., 1985. An empirical equation of state for hydrothermal seawater (3.2 percent $\mathrm{NaCl}$ ). American Journal of Science 285 (8), 725-763.

Both, R., Crook, K., Taylor, B., Brogan, S., Chappell, B., Frankel, E., Liu, L., Sinton, J., Tiffin, D., 1986. Hydrothermal chimneys and associated fauna in the Manus Back-Arc Basin, Papua New Guinea. Eos, Transactions American Geophysical Union 67 (21), 489-490.

Butterfield, D.A., Jonasson, I.R., Massoth, G.J., Feely, R.A., Roe, K.K., Embley, R.E., Holden, J.F., McDuff, R.E., Lilley, M.D., Delaney, J.R., 1997. Seafloor eruptions and evolution of hydrothermal fluid chemistry. Philosophical Transactions of the Royal Society of London Series a-Mathematical Physical and Engineering Sciences 355 (1723), 369-386.

Carazzo, G., Jellinek, A.M., Turchyn, A.V., 2013. The remarkable longevity of submarine plumes: Implications for the hydrothermal input of iron to the deep-ocean. Earth and Planetary Science Letters 382 (0), 66-76.

Charlou, J.-L., Donval, J.-P., 1993. Hydrothermal methane venting between $12^{\circ} \mathrm{N}$ and $26^{\circ} \mathrm{N}$ along the Mid-Atlantic Ridge. Journal of Geophysical Research: Solid Earth 98 (B6), 9625-9642.

Charlou, J.L., Bougault, H., Appriou, P., Jean-Baptiste, P., Etoubleau, J., Birolleau, A., 1991. Water column anomalies associated with hydrothermal activity between $11^{\circ} 40^{\prime}$ and $13^{\circ} \mathrm{N}$ on the East Pacific rise: discrepancies between tracers. Deep Sea Research Part A. Oceanographic Research Papers 38 (5), 569-596.

Charlou, J.L., Dmitriev, H., Bougault, H., Needham, H.D., 1988. Hydrothermal CH4 between $12^{\circ} \mathrm{N}$ and $15^{\circ} \mathrm{N}$ over the Mid-Atlantic Ridge. Deep Sea Research 35, 121-131.

Charlou, J.L., Donval, J.P., Fouquet, Y., Jean-Baptiste, P., Holm, N., 2002. Geochemistry of high $\mathrm{H} 2$ and $\mathrm{CH} 4$ vent fluids issuing from ultramafic rocks at the Rainbow hydrothermal field (36²'N, MAR). Chemical Geology 191 (4), 345-359.

Charlou, J.L., Donval, J.P., Jean-Baptiste, P., Dapoigny, A., Rona, P.A., 1996. Gases and helium isotopes in high temperature solutions sampled before and after ODP Leg 158 drilling at TAG Hydrothermal Field (26 N, MAR). Geophysical Research Letters 23 (23), 3491-3494. 
Charlou, J.L., Donval, J.P., Konn, C., Ondreas, H., Fouquet, Y., Jean Baptiste, P., Fourré, E., 2010. High production and fluxes of $\mathrm{H}_{2}$ and $\mathrm{CH}_{4}$ and evidence of abiotic hydrocarbon synthesis by serpentinization in ultramafic-hosted hydrothermal systems on the Mid-Atlantic Ridge. In: Rona, P., Devey, C., Dyment, J., Murton, B. (Eds.), Diversity of Hydrothermal Systems on Slow-spreading Ocean Ridges, Washington DC, pp. 265-296.

Charlou, J.L., Fouquet, Y., Bougault, H., Donval, J.P., Etoubleau, J., Jean-Baptiste, P., Dapoigny, A., Appriou, P., Rona, P.A., 1998. Intense $\mathrm{CH}_{4}$ plumes generated by serpentinization of ultramafic rocks at the intersection of the $15^{\circ} 20^{\prime} \mathrm{N}$ fracture zone and the Mid-Atlantic Ridge. Geochimica et Cosmochimica Acta 62 (13), 2323-2333.

Charlou, J.L., Rona, P., Bougault, H., 1987. Methane anomalies over TAG hydrotherma field on Mid-Atlantic Ridge. Journal of Marine Research 45 (2), 461-472.

Cowen, J.P., Massoth, G.J., Feely, R.A., 1990. Scavenging rates of dissolved manganese in a hydrothermal vent plume. Deep Sea Research Part A. Oceanographic Research Papers 37 (10), 1619-1637.

Craig, H., Horibe, Y., Farley, K.A., Welhan, J.A., Kim, K.R., Hey, R.N., 1987. Hydrothermal vents in the Mariana trough: Results of the first Alvin dives. Eos, Transactions American Geophysical Union 68 (44), 1531.

Cruse, A.M., Seewald, J.S., 2006. Geochemistry of low-molecular weight hydrocarbons in hydrothermal fluids from Middle Valley, northern Juan de Fuca Ridge. Geochimica et Cosmochimica Acta 70 (8), 2073.

Cruse, A.M., Seewald, J.S., 2010. Low-molecular weight hydrocarbons in vent fluids from the Main Endeavour Field, northern Juan de Fuca Ridge. Geochimica et Cosmochimica Acta 74 (21), 6126-6140.

de Angelis, M.A., Lilley, M.D., Baross, J.A., 1993. Methane oxidation in deep-sea hydrothermal plumes of the endeavour segment of the Juan de Fuca Ridge. Deep Sea Research Part I: Oceanographic Research Papers 40 (6), 1169-1186.

de Ronde, C.E.J., Baker, E.T., Massoth, G.J., Lupton, J.E., Wright, I.C., Sparks, R.J., Bannister, S.C., Reyners, M.E., Walker, S.L., Greene, R.R., Ishibashi, J., Faure, K., Resing, J.A., Lebon, G.T., 2007. Submarine hydrothermal activity along the mid-Kermadec Arc, New Zealand: Large-scale effects on venting. Geochemistry, Geophysics, Geosystems 8 (7), Q07007.

Dupré, S., Scalabrin, C., Grall, C., Augustin, J.-M., Henry, P., Şengör, A.M.C., Görür, N., Çağatay, M.N., Géli, L., 2015. Tectonic and sedimentary controls on widespread gas emissions in the Sea of Marmara: Results from systematic, shipborne multibeam echo sounder water column imaging. Journal of Geophysical Research: Solid Earth 120 (5), 28912912.

Dupré, S., Scalabrin, C., Pierre, D., Guerin, C. (2012) Acoustic mapping. Futuna 3 cruise report.

Dupré, S., Woodside, J., Klaucke, I., Mascle, J., and Foucher, J.P., 2010. Widespread active seepage activity on the Nile Deep Sea Fan (offshore Egypt) revealed by high-definition geophysical imagery. Marine Geology 275, 1-19.

Edmond, J.M., Measures, C., McDuff, R.E., Chan, L.H., Collier, R., Grant, B., Gordon, L.I., Corliss, J.B., 1979. Ridge crest hydrothermal activity and the balances of the major and minor elements in the ocean: The Galapagos data. Earth and Planetary Science Letters 46 (1), $1-18$.

Embley, R.W., Baker, E.T., Chadwick, W.W., Lupton, J.E., Resing, J.A., Massoth, G.J., Nakamura, K., 2004. Explorations of Mariana Arc volcanoes reveal new hydrothermal systems. Eos, Transactions American Geophysical Union 85 (4), 37-40. 
Ernst, G.G.J., Cave, R.R., German, C.R., Palmer, M.R., Sparks, R.S.J., 2000. Vertical and lateral splitting of a hydrothermal plume at Steinahóll, Reykjanes Ridge, Iceland. Earth and Planetary Science Letters 179 (3-4), 529-537.

Ernst, G.J., Davis, J., Sparks, R.S., 1994. Bifurcation of volcanic plumes in a crosswind. Bulletin of Volcanology 56 (3), 159-169.

Feely, R.A., Baker, E.T., Lebon, G.T., Gendron, J.F., Resing, J.A., Cowen, J.P., 1999. Evidence for iron and sulfur enrichments in hydrothermal plumes at Axial Volcano following the January-February 1998 eruption. Geophysical Research Letters 26 (24), 3649-3652.

Feely, R.A., Gendron, J.F., Baker, E.T., Lebon, G.T., 1994. Hydrothermal plumes along the East Pacific Rise, $8^{\circ} 40^{\prime}$ to $11^{\circ} 50^{\prime} \mathrm{N}$ : Particle distribution and composition. Earth and Planetary Science Letters 128 (1), 19-36.

Fouquet, Y., Vonstackelberg, U., Charlou, J.L., Donval, J.P., Foucher, J.P., Erzinger, J., Herzig, P., Muhe, R., Wiedicke, M., Soakai, S., Whitechurch, H., 1991. Hydrothermal activity in the Lau back-arc basin:Sulfides and water chemistry. Geology 19 (4), 303-306.

Fouquet, Y., Vonstackelberg, U., Charlou, J.L., Erzinger, J., Herzig, P.M., Muhe, R., Wiedicke, M., 1993. Metallogenesis in back-arc environments - the Lau Basin example. Economic Geology and the Bulletin of the Society of Economic Geologists 88 (8), 21542181.

Franklin, J.M., Gibson, H.L., Jonasson, I.R., and Galley, A.G., 2005, Volcanogenic Massive Sulfide Deposits, in: Hedenquist, J.W., Thompson, J.F.H., Goldfarb, R.J., and Richards, J.P. (Eds.), Economic Geology 100th Anniversary Volume. The Economic Geology Publishing Company, pp. 523-560.

Galley, A.G., Hannington, M.D., and Jonasson, I.R., 2007. Volcanogenic massive sulphide deposits, in: Goodfellow, W.D. (ed.), Mineral Deposits of Canada: A Synthesis of Major Deposit Types, District Metallogeny, the Evolution of Geological Provinces, and Exploration Methods. Geological Association of Canada, Mineral Deposits Division, Special Publication 5, pp. 141-161.

Gamo, T., Sakai, H., Ishibashi, J., Nakayama, E., Isshiki, K., Matsuura, H., Shitashima, K., Takeuchi, K., Ohta, S., 1993. Hydrothermal plumes in the eastern Manus Basin, Bismarck Sea: CH4, Mn, Al and pH anomalies. Deep Sea Research Part I: Oceanographic Research Papers 40 (11-12), 2335-2349.

German, C.R., Baker, E.T., Connelly, D.P., Lupton, J.E., Resing, J., Prien, R.D., Walker, S.L., Edmonds, H.N., Langmuir, C.H., 2006. Hydrothermal exploration of the Fonualei Rift and Spreading Center and the Northeast Lau Spreading Center. GEOCHEMISTRY GEOPHYSICS GEOSYSTEMS 7, Q11022.

German, C.R., Briem, J., Chin, C., Danielsen, M., Holland, S., James, R., Jónsdóttir, A., Ludford, E., Moser, C., Ólafsson, J., Palmer, M.R., Rudnicki, M.D., 1994. Hydrothermal activity on the Reykjanes Ridge: the Steinahóll vent-field at $63^{\circ} 06^{\prime} \mathrm{N}$. Earth and Planetary Science Letters 121 (3-4), 647-654.

German, C.R., Parson, L.M., 1998. Distributions of hydrothermal activity along the MidAtlantic Ridge: interplay of magmatic and tectonic controls. Earth and Planetary Science Letters 160 (3-4), 327-341.

German, C.R., Richards, K.J., Rudnicki, M.D., Lam, M.M., Charlou, J.L., 1998. Topographic control of a dispersing hydrothermal plume. Earth and Planetary Science Letters $156(3-4), 267-273$.

German, C.R., Thurnherr, A.M., Knoery, J., Charlou, J.L., Jean-Baptiste, P., Edmonds, H.N., 2010. Heat, volume and chemical fluxes from submarine venting: A synthesis of results from the Rainbow hydrothermal field, $36^{\circ} \mathrm{N}$ MAR. Deep Sea Research Part I: Oceanographic Research Papers 57 (4), 518-527. 
Grasshoff, K., 1970. A simultaneous multiple channel system for nutrient analysis in seawater with analog and digital data record. Advances in Automated Analysis; Mediad Inc, New York, 135-145.

Halbach, P., Nakamura, K.-i., Wahsner, M., Lange, J., Sakai, H., Kaselitz, L., Hansen, R.D., Yamano, M., Post, J., Prause, B., Seifert, R., Michaelis, W., Teichmann, F., Kinoshita, M., Marten, A., Ishibashi, J., Czerwinski, S., Blum, N., 1989. Probable modern analogue of Kuroko-type massive sulphide deposits in the Okinawa Trough back-arc basin. Nature 338 (6215), 496-499.

Hawkes, J.A., Rossel, P.E., Stubbins, A., Butterfield, D., Connelly, D.P., Achterberg, E.P., Koschinsky, A., Chavagnac, V., Hansen, C.T., Bach, W., Dittmar, T., 2015. Efficient removal of recalcitrant deep-ocean dissolved organic matter during hydrothermal circulation. Nature Geosci 8 (11), 856-860.

Hawkins, J., Helu, S., 1986. Polymetallics ulfided epositf rom a "blacks moker"chimney: Lau basin. Eos Trans. AGU 67, 378.

Haymon, R.M., Fornari, D.J., Von Damm, K.L., Lilley, M.D., Perfit, M.R., Edmond, J.M., Shanks III, W.C., Lutz, R.A., Grebmeier, J.M., Carbotte, S., Wright, D., McLaughlin, E., Smith, M., Beedle, N., Olson, E., 1993. Volcanic eruption of the mid-ocean ridge along the East Pacific Rise crest at $9^{\circ} 45-52^{\prime} \mathrm{N}$ : Direct submersible observations of seafloor phenomena associated with an eruption event in April, 1991. Earth and Planetary Science Letters 119 (12), 85-101.

Holden, J.F., Summit, M., Baross, J.A., 1998. Thermophilic and hyperthermophilic microorganisms in $3-30^{\circ} \mathrm{C}$ hydrothermal fluids following a deep-sea volcanic eruption. FEMS Microbiology Ecology 25 (1), 33-41.

Ishibashi, J.I., Grimaud, D., Nojiri, Y., Auzende, J.-M., Urabe, T., 1994. Fluctuation of chemical compositions of the phase-separated hydrothermal fluid from the North Fiji Basin Ridge. Marine Geology 116 (1-2), 215-226.

Jackett, D. R., McDougall, T. J., 1995. Minimal adjustment of hydrographic profiles to achieve static stability. Journal of Atmospheric and Oceanic Technology 12, 381-389.

Javoy, M., Pineau, F., 1991. The volatiles record of a "popping" rock from the MidAtlantic Ridge at $14^{\circ} \mathrm{N}$ : chemical and isotopic composition of gas trapped in the vesicles. Earth and Planetary Science Letters 107 (3-4), 598-611.

Jean-Baptiste, P., Andrié, C., Lelu, M., 1988. Mesure du couple tritium/hélium océanique par spectrométrie de masse. In: Guary, J.C., Guegueniat, P., Pentreath, R.J. (Eds.), Radionuclides: a tool for oceanography. Elsevier Science, Barking, p. 6.

Jean-Baptiste, P., Bougault, H., Vangriesheim, A., Charlou, J.L., Radford-Knoery, J., Fouquet, Y., Needham, D., German, C., 1998. Mantle 3He in hydrothermal vents and plume of the Lucky Strike site (MAR 37 Deg17'N) and associated geothermal heat flux. Earth and Planetary Science Letters 157 (1-2), 69-77.

Jean-Baptiste, P., Charlou, J.L., Stievenard, M., Donval, J.P., Bougault, H., Mevel, C., 1991. Helium and methane measurements in hydrothermal fluids from the mid-Atlantic ridge: The Snake Pit site at $23^{\circ} \mathrm{N}$. Earth and Planetary Science Letters 106 (1-4), 17-28.

Jean-Baptiste, P., Fourre, E., Charlou, J.-L., German, C.R., Radford-Knoery, J., 2004. Helium isotopes at the Rainbow hydrothermal site (Mid-Atlantic Ridge, 36 Deg14'N). Earth and Planetary Science Letters 221 (1-4), 325-335.

Jean-Baptiste, P., Fourré, E., Dapoigny, A., Baumier, D., Baglan, N., Alanic, G., 2010. 3 He mass spectrometry for very low-level measurement of organic tritium in environmental samples. Journal of Environmental Radioactivity 101 (2), 185-190.

Jean-Baptiste, P., Mantisi, F., Dapoigny, A., Stievenard, M., 1992. Design and performance of a mass spectrometric facility for measuring helium isotopes in natural waters 
and for low-level tritium determination by the 3He ingrowth method. International Journal of Radiation Applications and Instrumentation. Part A. Applied Radiation and Isotopes 43 (7), 881-891.

Kadko, D.C., Rosenberg, N.D., Lupton, J.E., Collier, R.W., Lilley, M.D., 1990. Chemical reaction rates and entrainment within the Endeavour Ridge hydrothermal plume. Earth and Planetary Science Letters 99 (4), 315-335.

Kawagucci, S., Okamura, K., Kiyota, K., Tsunogai, U., Sano, Y., Tamaki, K., Gamo, T., 2008. Methane, manganese, and helium-3 in newly discovered hydrothermal plumes over the Central Indian Ridge, $18^{\circ}-20^{\circ}$ S. Geochemistry, Geophysics, Geosystems 9 (10), Q10002.

Kim, S.L., Mullineaux, L.S., Helfrich, K.R., 1994. Larval dispersal via entrainment into hydrothermal vent plumes. Journal of Geophysical Research: Oceans 99 (C6), 12655-12665.

Klinkhammer, G., Rona, P., Greaves, M., Elderfield, H., 1985. Hydrothermal manganese plumes in the Mid-Atlantic Ridge rift valley. Nature 314 (6013), 727-731.

Klinkhammer, G.P., 1980. Observations of the distribution of manganese over the East Pacific Rise. Chemical Geology 29 (1-4), 211-226.

Klinkhammer, G.P., Bender, M.L., 1980. The distribution of manganese in the Pacific Ocean. Earth and Planetary Science Letters 46 (3), 361-384.

Kumagai, H., Tsukioka, S., Yamamoto, H., Tsuji, T., Shitashima, K., Asada, M., Yamamoto, F., and Kinoshita, M., 2010. Hydrothermal plumes imaged by high-resolution side-scan sonar on a cruising AUV, Urashima. Geochemistry, Geophysics, Geosystems 11 (12), Q12013.

Labanieh, S., Chazot, G., Etoubleau, J., Fouquet, Y., Dosso, L., Hemond, C., 2011. Origin of the seamounts near Futuna

Island, SW Pacific. Goldschmidt Conference, Prague.

Lavelle, J.W., Cowen, J.P., Massoth, G.J., 1992. A Model for the Deposition of Hydrothermal Manganese Near Ridge Crests. J. Geophys. Res. 97 (C5), 7413-7427.

Lilley, M.D., Butterfield, D.A., Olson, E.J., Lupton, J.E., Macko, S.A., McDuff, R.E., 1993. Anomalous $\mathrm{CH} 4$ and $\mathrm{NH} 4+$ concentrations at an unsedimented mid-ocean-ridge hydrothermal system. Nature 364 (6432), 45-47.

Lisitzin, A.P., Lukashin, V.N., Gordeev, V.V., McConachy, T.F., Scott, S.D., Shevchenko, V.P., 1997. Hydrological and geochemical anomalies associated with hydrothermal activity in SW Pacific marginal and back-arc basins. Marine Geology 142 (1-4), 7-45.

Love, B.A., Resing, J.A., Cowen, J.P., Lupton, J.E., Fornari, D.J., Shank, T.M., Biller, D., 2008. Methane, manganese, and helium in hydrothermal plumes following volcanic eruptions on the East Pacific Rise near 950'N. Geochem. Geophys. Geosyst. 9 (6), Q06T01.

Lupton, J., Rubin, K.H., Arculus, R., Lilley, M., Butterfield, D., Resing, J., Baker, E., Embley, R., 2015. Helium isotope, C/3He, and Ba-Nb-Ti signatures in the northern Lau Basin: Distinguishing arc, back-arc, and hotspot affinities. Geochemistry, Geophysics, Geosystems 16 (4), 1133-1155.

Lupton, J.E., Arculus, R.J., Resing, J., Massoth, G.J., Greene, R.R., Evans, L.J., Buck, N., 2012. Hydrothermal activity in the Northwest Lau Backarc Basin: Evidence from water column measurements. Geochemistry, Geophysics, Geosystems 13 (5), Q0AF04.

Lupton, J.E., Baker, E.T., Mottl, M.J., Sansone, F.J., Wheat, C.G., Resing, J.A., Massoth, G.J., Measures, C.I., Feely, R.A., 1993. Chemical and physical diversity of hydrothermal plumes along the East Pacific Rise, $8^{\circ} 45^{\prime} \mathrm{N}$ to $11^{\circ} 50^{\prime} \mathrm{N}$. Geophysical Research Letters 20 (24), 2913-2916.

Lupton, J.E., Pyle, D.G., Jenkins, W.J., Greene, R., Evans, L., 2004. Evidence for an extensive hydrothermal plume in the Tonga-Fiji region of the South Pacific. Geochemistry, Geophysics, Geosystems 5, Q01003. 
Massoth, G., Baker, E., Worthington, T., Lupton, J., de Ronde, C., Arculus, R., Walker, S., Nakamura, K., Ishibashi, J., Stoffers, P., Resing, J., Greene, R., Lebon, G., 2007. Multiple hydrothermal sources along the south Tonga arc and Valu Fa Ridge. Geochemistry, Geophysics, Geosystems 8, Q11008.

McCollom, T.M., 2000. Geochemical constraints on primary productivity in submarine hydrothermal vent plumes. Deep-Sea Research, Part I: Oceanographic Research Papers 47 (1), 85-101.

McCollom, T.M., 2013. Laboratory Simulations of Abiotic Hydrocarbon Formation in Earth's Deep Subsurface. Reviews in Mineralogy and Geochemistry 75 (1), 467-494.

McCollom, T.M., Seewald, J.S., 2007. Abiotic Synthesis of Organic Compounds in DeepSea Hydrothermal Environments. Chemical Reviews 107 (2), 382-401.

McLaughlin, West, E.A., Olson, E.J., Lilley, M.D., Resing, J.A., Lupton, J.E., Baker, E.T., Cowen, J.P., 1999. Variations in hydrothermal methane and hydrogen concentrations following the 1998 eruption at Axial Volcano. Geophys. Res. Lett. 26 (23), 3453-3456.

Meyer, J.L., Akerman, N.H., Proskurowski, G., Huber, J.A., 2013. Microbiological characterization of post-eruption "snowblower" vents at Axial Seamount, Juan de Fuca Ridge. Frontiers in Microbiology 4, 153.

Mittelstaedt, E., Escartín, J., Gracias, N., Olive, J.-A., Barreyre, T., Davaille, A., Cannat, M., Garcia, R., 2012. Quantifying diffuse and discrete venting at the Tour Eiffel vent site, Lucky Strike hydrothermal field. Geochemistry, Geophysics, Geosystems 13 (4), n/a-n/a.

Mottl, M.J., Sansone, F.J., Geoffrey Wheat, C., Resing, J.A., Baker, E.T., Lupton, J.E., 1995. Manganese and methane in hydrothermal plumes along the East Pacific Rise, $8^{\circ} 40^{\prime}$ to $11^{\circ} 50^{\prime} \mathrm{N}$. Geochimica et Cosmochimica Acta 59 (20), 4147-4165.

Mottl, M.J., Seewald, J.S., Wheat, C.G., Tivey, M.K., Michael, P.J., Proskurowski, G., McCollom, T.M., Reeves, E., Sharkey, J., You, C.F., Chan, L.H., Pichler, T., 2011. Chemistry of hot springs along the Eastern Lau Spreading Center. Geochimica et Cosmochimica Acta 75 (4), 1013-1038.

Mullin, J.B., Riley, J.P., 1955. The colorimetric determination of silicate with special reference to sea and natural waters. Analytica Chimica Acta 12 (0), 162-176.

Nakamura, K., Toki, T., Mochizuki, N., Asada, M., Ishibashi, J.-i., Nogi, Y., Yoshikawa, S., Miyazaki, J.-i., Okino, K., 2013. Discovery of a new hydrothermal vent based on an underwater, high-resolution geophysical survey. Deep Sea Research Part I: Oceanographic Research Papers 74 (0), 1-10.

Nercessian, O., Bienvenu, N., Moreira, D., Prieur, D., Jeanthon, C., 2005. Diversity of functional genes of methanogens, methanotrophs and sulfate reducers in deep-sea hydrothermal environments. Environmental Microbiology 7 (1), 118-132.

Ostlund, H.G., H. Craig, W.B. Broecker, D. Spencer, 1987. GEOSECS Atlantic, Pacific and Indian expeditions, shorebased data and graphics, vol.7, National Science Foundation, Washington DC.

Pelleter, E., Fouquet, Y., Etoubleau, J., Cheron, S., Josso, P., Labanieh, S., Langlade, J., parties, S., 2015. The Nickel-, Copper-, Cobalt-Rich Hydrothermal Manganese Deposits from the Wallis and Futuna Area, SW Pacific. In: André-Meyer, A.-S.e.a.e. (Ed.), Mineral Resources in a Sustainable World, Nancy, France.

Pelletier, B., 2003. Apport des travaux de géologie et de géophysique de l'équipe IRD (ex ORSTOM) du centre de Nouméa à la compréhension de l'origine et de l'évolution des archipels de Wallis et Futuna. Spécial DOM-TOM: Océan Pacifique (138), 81-88.

Pelletier, B., Calmant, S., Pillet, R., 1998. Current tectonics of the Tonga-New Hebrides region. Earth and Planetary Science Letters 164 (1-2), 263-276. 
Pelletier, B., Lagabrielle, Y., Benoit, M., Cabioch, G., Calmant, S., Garel, E., Guivel, C., 2001. Newly identified segments of the Pacific-Australia plate boundary along the North Fiji transform zone. Earth and Planetary Science Letters 193 (3-4), 347-358.

Pelletier, B., Lagabrielle, Y., Cabioch, G., Calmant, S., Régnier, M., Perrier, J., 2000. Transpression active le long de la frontière décrochante Pacifique-Australie: les apports de la cartographie multifaisceaux autour des îles Futuna et Alofi (Pacifique sud-ouest). Comptes Rendus de l'Académie des Sciences - Series IIA - Earth and Planetary Science 331 (2), 127 132.

Ramondenc, P., Germanovich, L.N., Von Damm, K.L., Lowell, R.P., 2006. The first measurements of hydrothermal heat output at $9^{\circ} 50$ N , East Pacific Rise. Earth and Planetary Science Letters 245 (3-4), 487-497.

Reeves, E.P., Seewald, J.S., Saccocia, P., Bach, W., Craddock, P.R., Shanks, W.C., Sylva, S.P., Walsh, E., Pichler, T., Rosner, M., 2011. Geochemistry of hydrothermal fluids from the PACMANUS, Northeast Pual and Vienna Woods hydrothermal fields, Manus Basin, Papua New Guinea. Geochimica et Cosmochimica Acta 75 (4), 1088-1123.

Reid, J.L., 1986. On the total geostrophic circulation of the South Pacific Ocean: Flow patterns, tracers and transports. Progress in Oceanography 16 (1), 1-61.

Reid, J.L., 1997. On the total geostrophic circulation of the pacific ocean: flow patterns, tracers, and transports. Progress in Oceanography 39 (4), 263-352.

Resing, J.A., Baker, E.T., Lupton, J.E., Walker, S.L., Butterfield, D.A., Massoth, G.J., Nakamura, K.-i., 2009. Chemistry of hydrothermal plumes above submarine volcanoes of the Mariana Arc. Geochem. Geophys. Geosyst. 10 (2), Q02009.

Resing, J.A., Rubin, K.H., Embley, R.W., Lupton, J.E., Baker, E.T., Dziak, R.P., Baumberger, T., Lilley, M.D., Huber, J.A., Shank, T.M., Butterfield, D.A., Clague, D.A., Keller, N.S., Merle, S.G., Buck, N.J., Michael, P.J., Soule, A., Caress, D.W., Walker, S.L., Davis, R., Cowen, J.P., Reysenbach, A.-L., Thomas, H., 2011. Active submarine eruption of boninite in the northeastern Lau Basin. Nature Geosci 4 (11), 799-806.

Resing, J.A., Sedwick, P.N., German, C.R., Jenkins, W.J., Moffett, J.W., Sohst, B.M., Tagliabue, A., 2015. Basin-scale transport of hydrothermal dissolved metals across the South Pacific Ocean. Nature 523 (7559), 200-203.

Roshan, S., Wu, J., 2015. The distribution of dissolved copper in the tropical-subtropical north Atlantic across the GEOTRACES GA03 transect. Marine Chemistry 176, 189-198.

Rudnicki, M., German, C., 2002. Temporal variability of the hydrothermal plume above the Kairei vent field, $25^{\circ} \mathrm{S}$, Central Indian Ridge. Geochemistry Geophysics Geosystems 3 (2), 1-11.

Rudnicki, M.D., James, R.H., Elderfield, H., 1994. Near-field variability of the TAG nonbuoyant plume, $26^{\circ} \mathrm{N}$, Mid-Atlantic Ridge. Earth and Planetary Science Letters 127 (1-4), 110.

Sansone, F.J., Resing, J.A., Tribble, G.W., Sedwick, P.N., Kelly, K.M., Hon, K., 1991. Lava-seawater interactions at shallow-water submarine lava flows. Geophysical Research Letters 18 (9), 1731-1734.

Schultz, A., Elderfield, H., 1997. Controls on the physics and chemistry of seafloor hydrothermal circulation. Philosophical Transactions of the Royal Society of London A: Mathematical, Physical and Engineering Sciences 355 (1723), 387-425.

Simoneit, B.R.T., Kawka, O.E., Brault, M., 1988. Origin of gases and condensates in the Guaymas Basin hydrothermal system (Gulf of California). Chemical Geology 71 (1-3), 169182. 
Sinton, J.M., Ford, L.L., Chapell, B., McCulloch, M.T., 2003. Magma Genesis and Mantle Heterogeneity in the Manus Back-Arc Basin, Papua New Guinea. Journal of Petrology 44 (1), 159-195.

Soule, S.A., Nakata, D.S., Fornari, D.J., Fundis, A.T., Perfit, M.R., Kurz, M.D., 2012. CO2 variability in mid-ocean ridge basalts from syn-emplacement degassing: Constraints on eruption dynamics. Earth and Planetary Science Letters 327-328 (0), 39-49.

Speer, K., Thurnherr, A.M., 2012. The Lau Basin Float Experiment (LAUB-FLEX). Oceanography 25 (1), 284-285.

Speer, K.G., Marshall, J., 1995. The growth of convective plumes at seafloor hot springs. Journal of Marine Research 53 (6), 1025-1057.

Staudigel, H., Hart, S.R., Koppers, A.A.P., Constable, C., Workman, R., Kurz, M., Baker, E.T., 2004. Hydrothermal venting at Vailulu'u Seamount: The smoking end of the Samoan chain. Geochem. Geophys. Geosyst. 5 (2), Q02003.

Stein, C.A., Stein, S., 1994. Constraints on hydrothermal heat flux through the oceanic lithosphere from global heat flow. Journal of Geophysical Research: Solid Earth 99 (B2), 3081-3095.

Strickland, J.D.H., Parsons, T.R., 1968. A Practical Handbook of Seawater Analysis.

Summit, M., Baross, J.A., 1998. Thermophilic subseafloor microorganisms from the 1996 North Gorda Ridge eruption. Deep Sea Research Part II: Topical Studies in Oceanography 45 (12), 2751-2766.

Swinnerton, J.W., Linnenbom, W., Cheek, C.H., 1962. Determination of disolved gases in aqueous solutions by gas chromatography. Analytical Chemistry 34, 483-485.

Tagliabue, A., Bopp, L., Dutay, J.-C., Bowie, A.R., Chever, F., Jean-Baptiste, P., Bucciarelli, E., Lannuzel, D., Remenyi, T., Sarthou, G., Aumont, O., Gehlen, M., Jeandel, C., 2010. Hydrothermal contribution to the oceanic dissolved iron inventory. Nature Geosci 3 (4), 252-256.

Takai, K., Gamo, T., Tsunogai, U., Nakayama, N., Hirayama, H., Nealson, K.H., Horikoshi, K., 2004. Geochemical and microbiological evidence for a hydrogen-based, hyperthermophilic subsurface lithoautotrophic microbial ecosystem (HyperSLiME) beneath an active deep-sea hydrothermal field. Extremophiles 8 (4), 269-282.

Urabe, T., Kusakabe, M., 1990. Barite silica chimneys from the Sumisu Rift, Izu-Bonin Arc: possible analog to hematitic chert associated with Kuroko deposits. Earth and Planetary Science Letters 100 (1-3), 283-290.

Ver Eecke, H.C., Butterfield, D.A., Huber, J.A., Lilley, M.D., Olson, E.J., Roe, K.K., Evans, L.J., Merkel, A.Y., Cantin, H.V., Holden, J.F., 2012. Hydrogen-limited growth of hyperthermophilic methanogens at deep-sea hydrothermal vents. Proceedings of the National Academy of Sciences 109 (34), 13674-13679.

Visbeck, M., Marshall, J., Jones, H., 1996. Dynamics of Isolated Convective Regions in the Ocean. Journal of Physical Oceanography 26 (9), 1721-1734.

Von Stackelberg, U.a.S.p., 1988. Active hydrothermalism in the Lau back-arc basin (SWPacific) first results from the SONNE 48 cruise (1987). Marine Mining 7, 431-442.

Welhan, J.A., 1988. Origins of methane in hydrothermal systems. Chemical Geology 71 (1-3), 183-198.

Welhan, J.A., Craig, H., 1983. Methane, Hydrogen and Helium in Hydrothermal Fluids at $21^{\circ} \mathrm{N}$ on the East Pacific Rise. In: Rona, P., Boström, K., Laubier, L., Smith, K., Jr. (Eds.), Hydrothermal Processes at Seafloor Spreading Centers. Springer US, pp. 391-409.

Welhan, J.A., Lupton, J.E., 1987. Light hydrocarbon gases in Guaymas Basin hydrothermal fluids; thermogenic versus abiogenic origin. AAPG Bulletin 71 (2), 215-223. 
Whitehead, J.A., Marshall, J., Hufford, G.E., 1996. Localized convection in rotating stratified fluid. Journal of Geophysical Research: Oceans 101 (C11), 25705-25721.

Wiens, D.A., Kelley, K.A., Plank, T., 2006. Mantle temperature variations beneath backarc spreading centers inferred from seismology, petrology, and bathymetry. Earth and Planetary Science Letters 248 (1-2), 30-42.

$\mathrm{Wu}$, J., Roshan, S., Chen, G., 2014. The distribution of dissolved manganese in the tropical-subtropical North Atlantic during US GEOTRACES 2010 and 2011 cruises. Marine Chemistry $166(0), 9-24$.

Xu, G., Di Iorio, D., 2012. Deep sea hydrothermal plumes and their interaction with oscillatory flows. Geochemistry, Geophysics, Geosystems 13 (9), Q0AJ01.

You, O.-R., Son, S.K., Baker, E.T., Son, J., Kim, M.J., Barcelona, M.J., Kim, M., 2014. Bathymetric influence on dissolved methane in hydrothermal plumes revealed by concentration and stable carbon isotope measurements at newly discovered venting sites on the Central Indian Ridge $\left(11-13^{\circ} \mathrm{S}\right)$. Deep Sea Research Part I: Oceanographic Research Papers 91 (0), 17-26.

\section{Figure captions}

Figure 1: General bathymetric map of the study area. Low resolution bathymetric data are from the ALOFI cruise (Pelletier et al., 2001) and high resolution data from the Futuna 1, 2 and 3 cruises (2010, 2011, 2012). Full circles mark all CTD/Rosette operations conducted during the Futuna 1 (green), 2 (red) and 3 (yellow) cruises. The white / black rim of these full circles stand for absence / presence of tracers anomaly. All structure names were chosen during those cruises except from the Futuna Ridge (ALOFI cruise, 2000).

Figure 2: (A) Bathymetric map of the Kulo Lasi Caldera (data from the Futuna 1 cruise). CTD/Rosette stations are represented by green full circles (Futuna 1) and red full circles (Futuna 2). A Tow-Yo transect was conducted in 2011 (Futuna 2) along the red line in the NW-SE direction. Each dot along this line marks a vertical profile referred as Px in the text. (B) Bathymetric map of the Amanaki area (data from the Futuna 1 cruise). CTD/Rosette stations are represented by green full circles (Futuna 1) and red full circles (Futuna 2). A Tow-Yo transect carried out in 2011 (Futuna 2) is represented by the red line (FU2HY-33 Tow-Yo). All stations within the yellow circle exhibited lower values of the geochemical tracers than at station FU2-HY-29. (C) Bathymetric map of the Fatu Kapa region (data from the Futuna 1 and 3 cruises). CTD/Rosette casts are represented by red full circles (Futuna 2) and yellow full circles (Futuna 3). Target symbols represent some of the fluid sources acoustic signals and putative hydrothermal vents 
that were given a name. The yellow line represents the FU3-HY-05 Tow-Yo operation transect. (D) Bathymetric map of the Tasi Tulo region (data from the Futuna 1 and 3 cruises). CTD/Rosette casts are represented by red full circles (Futuna 2) and yellow full circles (Futuna 3).

Figure 3: Global concentrations of $\mathrm{CH}_{4}$ in $\mathrm{nM}(\mathrm{A})$, TDM in $\mathrm{nM}(\mathrm{B})$ and $\delta^{3} \mathrm{He}$ in \% (C) measured in the water column (depth in $\mathbf{m})$ over the entire study area. These plots compile all hydrocasts data acquired during the Futuna 1, 2 and 3 cruises. Grey crosses are background values, full markers are Amanaki data, thin open markers are Kulo Lasi data, and thick open markers are Fatu Kapa and Tasi Tulo data. Circles stand for $\mathrm{CH}_{4}$, triangles for TDM and black crosses for $\delta^{3} \mathrm{He}$. The depth range of the different plumes is roughly indicated by the braces. Fatu Kapa and Tasi Tulo plumes occur at similar depth range and could not be distinguished on the plots. Stations NLH-14 (14 $\left.{ }^{\circ} 50.59 ' \mathrm{~S} / 175^{\circ} 56.49^{\prime} \mathrm{W}\right)$ and NLH-16 $\left(14^{\circ} 59.99 ' \mathrm{~S} / 176^{\circ} 00.01^{\prime} \mathrm{W}\right)$ represent the regional ${ }^{3} \mathrm{He}$ background of the nearby Northwest Lau Basin (see Fig. 5 in Lupton et al., 2012). Geosecs station 263 (16 ${ }^{\circ} 41^{\prime}$ 'S $\left./ 167^{\circ} 3^{\prime} \mathrm{W}\right)$ represents background ${ }^{3}$ He of the western Pacific east of the Tonga Trench (Ostlund et al., 1987).

Figure 4: This figure shows all the vertical profiles of nephelometry (red empty squares), $\mathrm{CH}_{4}$ (blue circles), TDM (green triangles) and $\delta^{3} \mathrm{He}$ (black plus) obtained inside and outside the Kulo Lasi Caldera, both in 2010 (Futuna 1) and 2012 (Futuna 2). Please refer to Figure 2A for location of the stations.

Figure 5: 2D-map of the nephelometry above the Kulo Lasi Caldera and along a NW-SE transect (left to right). Data of individual profiles recorded during the FU2-HY-22 Tow-Yo operation (shown in top panel) were interpolated and contoured using a MATLAB ${ }^{\circledR}$ program.

Figure 6: Tracer relations in the Kulo Lasi plume. Shallow waters gather the 900-1200 m layer data, deep waters the $>1300 \mathrm{~m}$ data and mixed layer the 1200-1300 $\mathrm{m}$ data. These distinctions apply only to 2010 data (Futuna 1). 2011 corresponds to data obtained during the Futuna 2 cruise.

Figure 7: This figure shows all the vertical profiles of nephelometry (red empty squares), $\mathrm{CH}_{4}$ (blue circles), TDM (green triangles) and $\delta^{3} \mathrm{He}$ (black plus) obtained in the Amanaki area. Please refer to Figure 2B for location of the CTD/rosette stations. 
Figure 8: This figure shows all the vertical profiles of nephelometry (red empty squares), $\mathrm{CH}_{4}$ (blue circles), TDM (green triangles) and and $\delta^{3} \mathrm{He}$ (black plus) recorded at Fatu Kapa. Data are presented West to East (left to right) and North to South (top to bottom). Please refer to Figure 2C for location of the CTD/rosette stations.

Figure 9: This figure shows all the vertical profiles of $\mathrm{CH}_{4}$ (blue circles), TDM (green triangles) and $\delta^{3} \mathrm{He}$ (black plus) recorded at Tasi Tulo. Nephelometry was recorded but is not shown for clarity since no anomalies were detected. Please refer to Figure 2D for location of the CTD/rosette stations.

Tables

Table 1 : Maximum value of $\mathrm{CH} 4$ and $\mathrm{Mn}$ in hydrothermal plumes over the world. These values are indicative as they are affected by the distance to the source. Ratios were obtained by regression if not otherwise mentionned. When only maximum values were available, an estimation of the ratio was calculated by regression between the background values of the area and the maximum values $\left({ }^{\max }\right)$. If exact values did not appear in the text, estimation were made by reading values on figures $(*)$. Calculated values from published data are in bold.

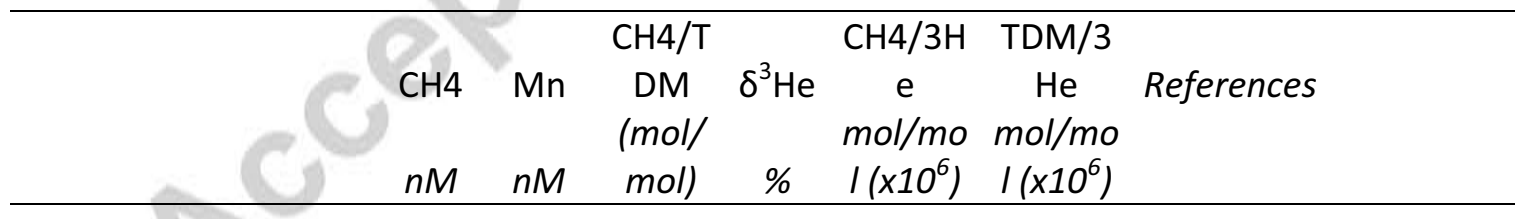

\section{FUTUNA}

Non buoyant

plumes

\begin{tabular}{lccccccc} 
Fatu Kapa & 11.2 & 34.7 & 0.78 & $72^{\mathrm{c}}$ & $1.3^{\mathrm{d}}$ & $4.2^{\mathrm{d}}$ & This work \\
$\quad \begin{array}{l}\text { Tasi Tulo } \\
\text { Kulo Lasi 2010 }\end{array}$ & 4.9 & 14.3 & 0.36 & $83^{\mathrm{c}}$ & $1.3^{\mathrm{d}}$ & $4.2^{\mathrm{d}}$ & This work \\
$\quad \begin{array}{l}\text { Shallow waters } \\
(900-1200 \mathrm{~m})\end{array}$ & $\begin{array}{c}34.3 \\
\mathrm{a}\end{array}$ & $28.7^{\mathrm{a}}$ & 0.70 & 104 & 6.4 & 11.1 & This work \\
$\quad \begin{array}{c}\text { Deep waters (> } \\
1300 \mathrm{~m})\end{array}$ & $\begin{array}{c}50.5 \\
a^{\mathrm{a}}\end{array}$ & $76.4^{\mathrm{a}}$ & 4.70 & 109 & 50.4 & 11.1 & This work \\
\hline
\end{tabular}




\begin{tabular}{|c|c|c|c|c|c|c|c|}
\hline Kulo Lasi 2011 & $5.3^{b}$ & $35.9^{b}$ & 0.12 & 99 & 2.0 & 11.5 & This work \\
\hline Amanaki & 3.1 & 46.8 & 0.07 & 74 & 2 & 27 & This work \\
\hline \multicolumn{8}{|l|}{ Buoyant plumes } \\
\hline \multicolumn{8}{|l|}{ (Fatu Kapa area) } \\
\hline \multicolumn{8}{|l|}{ Stéphanie (no } \\
\hline nephel) & 49.6 & 54.3 & 0.86 & - & - & - & This work \\
\hline \multirow[t]{2}{*}{ Idef $^{x}$ (no nephel) } & 58.1 & 47.1 & 1.43 & - & - & - & This work \\
\hline & 108. & & & & & & \\
\hline Obel $^{x} \quad$ (no nephel) & 9 & 52.5 & 1.68 & - & - & - & This work \\
\hline Fati Ufu (nephel) & 23.7 & 47.8 & 0.47 & - & 301 & 596 & This work \\
\hline \multicolumn{8}{|l|}{ Fast Spreading } \\
\hline \multicolumn{8}{|l|}{ Ridges } \\
\hline EPR $8^{\circ} 42^{\prime}-9^{\circ} 08^{\prime} \mathrm{N}$ & 5.5 & 42.0 & 0.07 & - & - & - & Mottl et al., 1995 \\
\hline EPR $9^{\circ} 08^{\prime}-9^{\circ} 39^{\prime} \mathrm{N}$ & 33.0 & 24.0 & 0.51 & - & - & - & Mottl et al., 1995 \\
\hline & & & & & $11.5^{* \text { ma }}$ & & Mottl et al., 1995 ; \\
\hline EPR $9^{\circ} 39^{\prime}-9^{\circ} 53^{\prime} \mathrm{N}$ & 89.0 & 18.0 & 10.5 & $70 *$ & $x$ & - & Lupton et al., 1993 \\
\hline EPR $9^{\circ} 53^{\prime}-10^{\circ} 07^{\prime} \mathrm{N}$ & 35.0 & 37.0 & 0.85 & - & - & - & Mottl et al., 1995 \\
\hline \multirow[t]{2}{*}{ EPR $10^{\circ} 30^{\prime}-11^{\circ} 52^{\prime} \mathrm{N}$} & 5.9 & 76.0 & 0.08 & - & - & - & Mottl et al., 1995 \\
\hline & & & & & $71 * \max$ & & Mottl et al., 1995 ; \\
\hline \multirow{2}{*}{$\mathrm{EPR}-13^{\circ} \mathrm{N}$} & $\begin{array}{l}5.9 \\
81\end{array}$ & $\begin{array}{l}16.0 \\
370\end{array}$ & $\begin{array}{l}0.08 \\
0.13\end{array}$ & $\begin{array}{l}15^{3} \\
774\end{array}$ & 7.130 & - & $\begin{array}{l}\text { Lupton et al., } 1993 \\
\text { Charlou et al } 1991\end{array}$ \\
\hline & & & & & & & Kim, 1983 ; Lupton et \\
\hline $\mathrm{EPR}-21^{\circ} \mathrm{N}$ & 0.7 & 128.0 & 0.05 & 46 & $5.0-6.3$ & 17.4 & $\begin{array}{l}\text { al., 1980; Lilley et al., } \\
1982\end{array}$ \\
\hline EPR $19^{\circ} 30-20^{\circ} \mathrm{S}$ & - & & 0.13 & - & $\begin{array}{l}7.0- \\
20.6\end{array}$ & - & Kim, 1983 \\
\hline \multicolumn{8}{|l|}{$27.5^{\circ} \mathrm{S} \sim 32.5^{\circ} \mathrm{S}$} \\
\hline (Eastern plume) & 23.7 & -9 & 0.09 & - & 3.7 & 48.1 & Gharib et al;, 2005 \\
\hline \multicolumn{8}{|l|}{$27.5^{\circ} \mathrm{S} \sim 32.5^{\circ} \mathrm{S}$} \\
\hline (Western plume) & 16.8 & - & 0.08 & - & 17.1 & 187.1 & Gharib et al;, 2005 \\
\hline \multicolumn{8}{|l|}{$\begin{array}{l}\text { Intermediate } \\
\text { spreading ridges }\end{array}$} \\
\hline \multicolumn{8}{|l|}{ Dodo GLP $18^{\circ} 20^{\prime} S$} \\
\hline$(C 25)$ & 36.7 & 8.7 & $\sim 4$ & - & - & - & Kawagucci et al., 2008 \\
\hline \multicolumn{8}{|l|}{ Dodo GLP $18^{\circ} 20^{\prime} S$} \\
\hline (Upper plume) & 18.4 & 6.3 & $\sim 0.5$ & 35 & - & $\sim 9$ & Kawagucci et al., 2008 \\
\hline \multicolumn{8}{|l|}{ Dodo GLP $18^{\circ} 20^{\prime} S$} \\
\hline (Bottom plume) & 30.3 & 5.3 & $\sim 6$ & 33 & $>60$ & $\sim 9$ & Kawagucci et al., 2008 \\
\hline \multicolumn{8}{|l|}{ CIR $19^{\circ} 34^{\prime}$ 'S Roger } \\
\hline palteau & 7.0 & 7.0 & $\sim 1$ & 56 & 4.0 & $\sim 5$ & $\begin{array}{l}\text { Kawagucci et al., } 2008 \\
\text { Plüger et al., 1990; }\end{array}$ \\
\hline $\mathrm{CIR} 24^{\circ} \mathrm{S}$ & 9.0 & 23.1 & 0.41 & - & - & - & Mottl et al., 1995 \\
\hline CIR $25^{\circ} 17^{\prime}-25^{\circ} 26^{\prime} \mathrm{S}$ & 3.3 & 9.8 & 0.27 & - & - & - & Gamo et al., 1996 \\
\hline
\end{tabular}




\begin{tabular}{|c|c|c|c|c|c|c|c|}
\hline & & & $0.42^{\mathrm{ma}}$ & & & & \\
\hline RTJ $25^{\circ} 32^{\prime} \mathrm{S}$ & 1.3 & 3.0 & $0.23^{\mathrm{ma}}$ & - & - & - & Gamo et al., 1996 \\
\hline SEIR $25^{\circ} 40^{\prime} \mathrm{S}$ & 0.7 & 2.5 & $x$ & - & - & - & Gamo et al., 1996 \\
\hline \multicolumn{8}{|l|}{$\begin{array}{l}\text { Slow spreading } \\
\text { ridges }\end{array}$} \\
\hline JdF Endeavour & 390 & & & & 78- & & Rosenberg et al., 1988 \\
\hline $47^{\circ} 57^{\prime} \mathrm{N}$ & $*$ & 46.0 & $7-12 *$ & 52 & $152 *$ & $\begin{array}{l}6-21 * \\
22.5-\end{array}$ & $\begin{array}{l}\text {; Kadko et al., } 1990 \\
\text { Baker et al., } 2011 \text { and }\end{array}$ \\
\hline JdF (event plumes) & - & - & - & - & - & 97.6 & ref therein \\
\hline JdF norht Cleft & - & $\begin{array}{l}48- \\
263\end{array}$ & $\begin{array}{c}0.45- \\
0.78\end{array}$ & $\begin{array}{l}83- \\
204\end{array}$ & - & 85.1 & $\begin{array}{l}\text { Mottl et al., } 1995 \\
\text { Massoth et al., } 1994\end{array}$ \\
\hline & & $14-$ & $0.11^{\mathrm{ma}}$ & $33-$ & & $16.1-$ & Winn et al., 1986 ; \\
\hline JdF south Cleft & 3.0 & 156 & $x$ & 69 & - & 80.0 & Massoth et al., 1994 \\
\hline $\begin{array}{l}\text { JdF Cleft (event } \\
\text { plumes) }\end{array}$ & & $\begin{array}{l}56- \\
191\end{array}$ & - & $\begin{array}{l}74- \\
108\end{array}$ & - & $\begin{array}{l}24.6- \\
59.8\end{array}$ & Massoth et al., 1994 \\
\hline Gorda ridge $42^{\circ} 45^{\prime} \mathrm{N}$ & 10.3 & 10.0 & $1.1^{\max }$ & 52 & - & 7.5 & Baker et al., 1987 \\
\hline $\begin{array}{l}\text { TAG } 26^{\circ} \mathrm{N} \text { (MAR) } \\
\text { non-buoyant }\end{array}$ & 9.5 & $\begin{array}{l}37 * \\
102\end{array}$ & 0.28 & - & & & $\begin{array}{l}\text { Charlou et al., } 1993 \\
\text { Rusakov et al., } 2009\end{array}$ \\
\hline $\begin{array}{l}\text { TAG } 26^{\circ} \mathrm{N}(\mathrm{MAR}) \\
\text { buoyant }\end{array}$ & $\begin{array}{c}672 . \\
7\end{array}$ & $\begin{array}{c}7000 . \\
0\end{array}$ & 0.10 & & & 35.6 & $\begin{array}{l}\text { Charlou et al., } 1993 \text {; } \\
\text { Rudnicki and } \\
\text { Elderfield, } 1992\end{array}$ \\
\hline $\begin{array}{l}\text { Snake Pit } 23^{\circ} \mathrm{N} \\
\text { (MAR) non-buyant }\end{array}$ & 2.3 & - & & & - & - & Charlou et al., 1993 \\
\hline $\begin{array}{l}\text { Snake Pit } 23^{\circ} \mathrm{N} \\
\text { (MAR) buoyant }\end{array}$ & $\begin{array}{c}326 . \\
8\end{array}$ & $\begin{array}{c}3850 . \\
0\end{array}$ & 0.09 & - & - & 38.9 & $\begin{array}{l}\text { Charlou et al., } 1993 \text {; } \\
\text { Rudnicki and } \\
\text { Elderfield, } 1992\end{array}$ \\
\hline Broken Spur & & 2.1 & - & - & - & - & $\begin{array}{l}\text { Rusakov et al., } 2009 \\
\text { Baker et al., } 2011\end{array}$ \\
\hline Lucky Strike $\left(37^{\circ} \mathrm{N}\right)$ & & 9.3 & & $\begin{array}{c}19.0 \\
5\end{array}$ & - & 24.1 & $\begin{array}{l}\text { Jean-Baptiste et al., } \\
\text { 1998; Aballéa et al., } \\
1998\end{array}$ \\
\hline Reykjanes Ridge & & & & & & & \\
\hline $63^{\circ} \mathrm{N}$ & 18.0 & 60.0 & 0.3 & - & - & - & German et al., 1994 \\
\hline Rainbow $36^{\circ} \mathrm{N}$ & 170 & & & & & & Jean-Baptiste et al., \\
\hline (MAR) & $*$ & $160 *$ & 1.2 & 37 & 131.0 & 110.0 & 2004 \\
\hline North ATJ $\left(38-40^{\circ} \mathrm{N}\right)$ & - & 3.5 & - & - & - & - & Aballéa et al., 1998 \\
\hline $15^{\circ} \mathrm{N}(\mathrm{MAR})$ & 17.8 & $1.9 *$ & 9.09 & - & - & - & Charlou et al., 1993 \\
\hline Logatchev $14^{\circ} 45^{\prime} \mathrm{N}$ & 323. & & $2.56^{\mathrm{ma}}$ & & & & \\
\hline (MAR) & 0 & 127.0 & $x$ & - & - & - & Marbler et al., 2010 \\
\hline Logatchev $14^{\circ} 45^{\prime} \mathrm{N}$ & 100 & & & & & & \\
\hline (MAR) & $*$ & - & - & $35^{*}$ & 94.0 & - & Schmale et al., 2012 \\
\hline $\begin{array}{l}\text { Nibelungen } 8^{\circ} \mathrm{S} \\
\text { (MAR) }\end{array}$ & $\begin{array}{c}115 . \\
0\end{array}$ & 25.0 & $4.6^{\max }$ & - & - & - & Devey et al., 2005 \\
\hline
\end{tabular}




\begin{tabular}{|c|c|c|c|c|c|c|c|}
\hline Turtle Pits $5^{\circ} \mathrm{S}$ & & & $0.46^{\mathrm{ma}}$ & & & & \\
\hline (MAR) & 65.6 & 142.0 & $x$ & - & - & - & Marbler et al., 2010 \\
\hline Lilliput $9^{\circ} 33^{\prime} \mathrm{S}$ & & & & & & & \\
\hline (MAR) & 57.5 & - & - & - & - & - & Haase et al., 2009 \\
\hline Drachenschlund & 202. & & & & & & \\
\hline $8^{\circ} 18^{\prime} \mathrm{S}$ (MAR) & 1 & $>10$ & - & 19.1 & 408.0 & - & Keir et al., 2008 \\
\hline $\begin{array}{l}\text { Edmond } \\
\text { Carlsberg Ridge (62 }\end{array}$ & - & $85^{*}$ & - & - & - & - & Sands et al., 2012 \\
\hline $\begin{array}{l}\left.-66^{\circ} \mathrm{E}\right) \\
\text { Ultraslow } \\
\text { spreading ridges }\end{array}$ & - & 2.7 & - & 16.9 & - & 8.0 & Ray et al., 2012 \\
\hline SWIR $37^{\circ} 47^{\prime} \mathrm{N}$ & - & 10.4 & $0.33^{\mathrm{ma}}$ & - & - & - & Wang et al., 2012 \\
\hline SWIR $25^{\circ} 48^{\prime} S$ & 0.7 & 2.0 & $x$ & - & - & - & Gamo et al., 1996 \\
\hline Back arc basins & & & $\begin{array}{l}0.10- \\
0.41^{\mathrm{ma}}\end{array}$ & & & 24.4- & Auzende et al., 1988 ; \\
\hline $\begin{array}{l}\text { N-Fidji } 16-20^{\circ} \mathrm{S} \\
\text { N-Fidji } 19^{\circ} \mathrm{S} \text { (lower }\end{array}$ & 12.8 & - & $x$ & 71 & 10 & 100 & Craig et al., 1987 \\
\hline $\begin{array}{l}=\text { deep plume) } \\
\mathrm{N}-\text { Fidji } 19^{\circ} \mathrm{S} \text { (mega }\end{array}$ & - & - & 0.06 & - & & - & Nojiri et al., 1989 \\
\hline plume) & - & - & 0.39 & - & - & - & Nojiri et al., 1989 \\
\hline $\begin{array}{l}\text { Okinawa Trough } \\
\text { Manus }\end{array}$ & 29.1 & 9.8 & 2.08 & 65 & 32.0 & 3.9 & Ishibashi et al., 1988 \\
\hline $\begin{array}{l}\text { East-Manus (deep } \\
\text { plume) }\left(3^{\circ} 40^{\prime} \mathrm{S}\right)\end{array}$ & $2^{*}$ & $\begin{array}{l}(31.7) \\
-99.7\end{array}$ & $\begin{array}{l}0.02- \\
0.05\end{array}$ & - & - & - & $\begin{array}{l}\text { Gamo et al., } 1993 \\
\text { (Lisitzin et al., 1997) }\end{array}$ \\
\hline $\begin{array}{l}\text { East-Manus } \\
\text { (shallow = mega } \\
\text { plume) } \\
\text { Manus High }\end{array}$ & 6.5 & $20 *$ & 0.29 & - & - & - & Gamo et al., 1993 \\
\hline $\begin{array}{l}\left(3^{\circ} 30^{\prime} \mathrm{S}\right) \\
\quad \text { Central-Manus }\end{array}$ & & $\begin{array}{c}33.3 \\
(44.8)\end{array}$ & - & - & - & - & $\begin{array}{l}\text { Lisitzin et al., } 1997 \\
\text { Gamo et al., } 1993 \text {; }\end{array}$ \\
\hline$\left(3^{\circ}-3^{\circ} 20^{\prime} S\right)$ & 20.6 & $-70 *$ & 0.26 & - & - & - & (Lisitzin et al., 1997) \\
\hline $\begin{array}{l}\text { Lau Basin } \\
\text { NELSC (event }\end{array}$ & & & & & & & \\
\hline $\begin{array}{l}\text { plume })\left(15^{\circ} \mathrm{S}\right) \\
\text { NELSC (chronic }\end{array}$ & - & (4.7)- & - & - & - & 97.6 & $\begin{array}{l}\text { Baker et al., } 2011 \\
\text { Kim et al., 2009; }\end{array}$ \\
\hline plume $\left(15^{\circ} \mathrm{S}\right)$ & 14.1 & $\begin{array}{l}350 \\
9.4-\end{array}$ & $0.04 *$ & & & & $\begin{array}{l}\text { (Lisitzin et al., 1997) } \\
\text { Kim et al., 2009 }\end{array}$ \\
\hline MTJ (15³0'S) & $1.9^{*}$ & (10.9) & $0.18^{*}$ & - & - & & $\begin{array}{l}\text { (Lisitzin et al., 1997) } \\
\text { German et al., 2006 ; }\end{array}$ \\
\hline FRSC $\left(16^{\circ} 30^{\prime} \mathrm{S}\right)$ & 1.0 & 13.4 & - & 41 & - & 23.2 & Kim et al., 2009 \\
\hline $\operatorname{CLSC}\left(18^{\circ} 30^{\prime} \mathrm{S}\right)$ & - & 5.1 & - & - & - & - & Lisitzin et al., 1997 \\
\hline $\operatorname{ELSC}\left(20^{\circ} \mathrm{S}\right)$ & - & 45.5 & - & - & - & - & Lisitzin et al., 1997 \\
\hline
\end{tabular}




\begin{tabular}{|c|c|c|c|c|c|c|c|}
\hline $\begin{array}{l}\text { Valu Fa Ridge } \\
\left(22^{\circ} \mathrm{S}\right)\end{array}$ & $\begin{array}{l}1.7- \\
3.7\end{array}$ & $\begin{array}{l}13- \\
197\end{array}$ & $\begin{array}{c}0.02- \\
0.13^{\mathrm{ma}} \\
\mathrm{x}\end{array}$ & $\begin{array}{l}39- \\
50\end{array}$ & $\begin{array}{l}0.7- \\
1.5^{\max }\end{array}$ & $\begin{array}{c}5.5- \\
69.9^{\max }\end{array}$ & Massoth et al., 2007 \\
\hline Central caldera & - & 214.9 & - & 94.8 & - & 1100 & Lupton et al., 2012 \\
\hline Southern Caldera & - & 14.9 & - & 52 & - & - & Lupton et al., 2012 \\
\hline Lobster Caldera & - & $\begin{array}{l}51.9 \\
5.0-\end{array}$ & - & 239 & - & 7.6 & Lupton et al., 2012 \\
\hline $\begin{array}{l}\text { East Scotia } \\
\text { Coriolis Trough }\end{array}$ & - & 6.0 & - & - & - & - & $\begin{array}{l}\text { German et al., } 2000 \\
\text { McConachy et al., }\end{array}$ \\
\hline $\begin{array}{l}\text { Vanuatu } \\
\text { Woodlark basin } \\
\text { (east) }\end{array}$ & 3.4 & 15.1 & - & - & - & - & Lisitzin et al., 1997 \\
\hline $\begin{array}{l}\text { Woodlark basin } \\
\text { (central) }\end{array}$ & - & 118.3 & - & - & - & - & Lisitzin et al., 1997 \\
\hline Volcanic arcs & $3.2-$ & & $\begin{array}{l}0.03- \\
3.20^{\mathrm{ma}}\end{array}$ & $18-$ & 1.1- & $1.7-$ & \\
\hline South Tonga & 7.1 & $4-108$ & $\begin{array}{c}x \\
0.02-\end{array}$ & 73 & $2.1^{\max }$ & $32.9^{\max }$ & Massoth et al., 2007 \\
\hline $\begin{array}{l}\text { Marianna }\left(13.5^{\circ}-\right. \\
\left.23.2^{\circ} \mathrm{N}\right)\end{array}$ & $\begin{array}{c}1.6- \\
94\end{array}$ & $\begin{array}{l}3.2- \\
214\end{array}$ & $\underset{x}{1.62^{\mathrm{ma}}}$ & $\begin{array}{c}8- \\
314\end{array}$ & $\begin{array}{r}0.6-7.0- \\
(21.5)\end{array}$ & $\begin{array}{l}3.9- \\
83.3\end{array}$ & $\begin{array}{l}\text { Resing et al. } 2009 ; \\
\text { Horibe et al., } 1986\end{array}$ \\
\hline Mid-Kermadec & $\begin{array}{l}1.7- \\
8.1\end{array}$ & $4-303$ & $\begin{array}{c}0.02- \\
0.53^{\text {ma }} \\
x\end{array}$ & $8-65$ & $\begin{array}{l}0.7- \\
2.4^{\max }\end{array}$ & $\begin{array}{c}0.8- \\
112^{\max }\end{array}$ & deRonde et al., 2007 \\
\hline Hot spots & & & & & & & \\
\hline $\begin{array}{l}\text { Teahitia Seamount } \\
\text { Macdonald }\end{array}$ & $\begin{array}{l}0.87 \\
(14) \\
351 .\end{array}$ & $\begin{array}{l}18.8 \\
(60)\end{array}$ & $\mathrm{nl}$ & - & - & - & $\begin{array}{l}\text { Stuben et al., } 1992 \text {; (2 } \\
\text { year earlier cruise) }\end{array}$ \\
\hline Seamount & 0 & 255.0 & 1.31 & - & - & - & Stuben et al., 1992 \\
\hline Lo'ihi seamount & 25.7 & $20.5^{*}$ & $\begin{array}{l}0.26- \\
0.33^{\text {ma }} \\
x\end{array}$ & $\begin{array}{l}400- \\
2000\end{array}$ & 0.47 & $\begin{array}{c}0.14- \\
1.1\end{array}$ & $\begin{array}{l}\text { Sakai et al., } 1987 \text {; } \\
\text { Mottl et al., } 1995\end{array}$ \\
\hline $\begin{array}{l}\text { Dispersing Plume } \\
\text { (1996 -collapse) } \\
\text { Dispersing Plume }\end{array}$ & - & 236.0 & - & - & - & - & Malahoff et al., 2006 \\
\hline $\begin{array}{l}\text { (1996 -6 weeks) } \\
\text { Dispersing Plume }\end{array}$ & - & 67.0 & - & - & - & - & Malahoff et al., 2006 \\
\hline (1997-1998) & - & $19-22$ & - & - & - & - & Malahoff et al., 2006 \\
\hline Easter Island & 2.5 & - & - & 965 & 0.2 & - & Craig et al., 1984 \\
\hline Azores & - & 2.0 & - & - & - & - & Aballéa et al., 1998 \\
\hline \multicolumn{8}{|l|}{ Others } \\
\hline
\end{tabular}




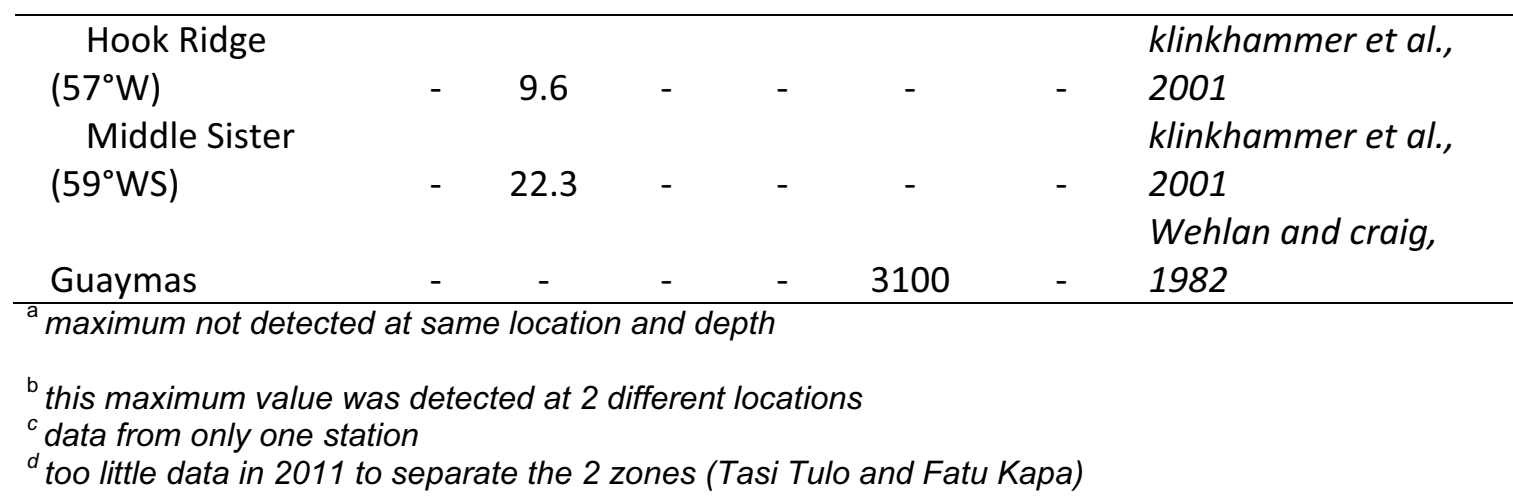

Table 2 : Major features about the main geological structures of the study area

\begin{tabular}{|c|c|c|c|c|c|}
\hline & $\begin{array}{c}\text { Volcano/ } \\
\text { tectonic } \\
\text { context }\end{array}$ & Rock type & $\begin{array}{c}\text { Depth } \\
\text { (m) }\end{array}$ & $\begin{array}{c}\text { Plume } \\
\text { height } \\
\text { (m) }\end{array}$ & ${ }^{3} \mathrm{He}{ }^{A} \mathrm{He}$ \\
\hline $\begin{array}{l}\text { Futuna } \\
\text { Ridge }\end{array}$ & inactive ridge & basalt & 700 & $\mathrm{n} / \mathrm{a}$ & 7.2 \\
\hline Kulo Lasi & $\begin{array}{l}\text { volcano with } \\
\text { caldera }\end{array}$ & $\begin{array}{c}\text { basalt }+ \\
\text { trachyandesite }\end{array}$ & 1500 & $\begin{array}{l}\sim 1150 \text { to } \\
\text { seafloor }\end{array}$ & 9.1 \\
\hline Amanaki's & ridge & $\begin{array}{c}\text { MORB-type } \\
\text { basalt }\end{array}$ & 2400 & $\sim 1900$ & 9.0 \\
\hline Fatu Kapa & $\begin{array}{l}\text { diffuse } \\
\text { volcanic } \\
\text { activity }\end{array}$ & $\begin{array}{c}\text { basalt, andesite } \\
\text { and rhyolite }\end{array}$ & $\begin{array}{c}1600 \\
- \\
1700\end{array}$ & $\begin{array}{c}\sim 1300 \text { to } \\
1700\end{array}$ & 8.8 \\
\hline Tasi Tulo & $\begin{array}{c}\text { graben }+ \\
\text { central } \\
\text { volcano }\end{array}$ & basalt & $\begin{array}{c}1700 \\
- \\
1900\end{array}$ & $\begin{array}{c}\sim 1300 \text { to } \\
1600\end{array}$ & 8.8 \\
\hline
\end{tabular}


Table 3: Concentration of the tracers along Tow-Yo transects.

\begin{tabular}{|c|c|c|c|c|c|c|}
\hline $\begin{array}{l}\text { Site } \\
\text { Station }\end{array}$ & $\begin{array}{c}\text { Profile } \\
\#\end{array}$ & $\begin{array}{c}\text { Depth } \\
m \\
\end{array}$ & $\begin{array}{c}\text { Nephel } \\
\text { NTU }\end{array}$ & $\begin{array}{c}{\left[\mathrm{CH}_{4}\right]} \\
n M \\
\end{array}$ & $\begin{array}{c}\text { TDM } \\
n M \\
\end{array}$ & $\begin{array}{c}\delta^{3} \mathrm{He} \\
\% \\
\end{array}$ \\
\hline Kulo Lasi & P2 & 1164 & 0.017 & 0.6 & 1.9 & 35.5 \\
\hline FU2-HY-22 tow-yo & P3 & 1162 & 0.015 & 0.4 & 1 & 28.9 \\
\hline \multirow[t]{14}{*}{$N W$ to $S E$} & P4 & 1160 & 0.02 & 0.5 & 1 & 29.4 \\
\hline & P5 & 1311 & 0.116 & 5.1 & 35.9 & 80.6 \\
\hline & P6 & 1313 & 0.088 & 3.9 & 17 & 76.2 \\
\hline & P7 & 1313 & 0.085 & 4.2 & 20.6 & 77.1 \\
\hline & P8 & 1311 & 0.08 & 4.7 & 21.6 & 75.2 \\
\hline & P9 & 1312 & 0.085 & 4.1 & 23.9 & 91.2 \\
\hline & P10 & 1313 & 0.102 & 4.3 & 17.6 & 82.4 \\
\hline & P11 & 1313 & 0.039 & 3.5 & 22.4 & 80.2 \\
\hline & P12 & 1317 & 0.038 & 3.9 & 29.1 & 82.6 \\
\hline & P13 & 1313 & 0.062 & 3.4 & 21.7 & 99.1 \\
\hline & P14 & 1312 & 0.228 & 4.7 & 18.8 & 95.9 \\
\hline & P15 & 1156 & 0.057 & 1.8 & 5.8 & 58.5 \\
\hline & P16 & 1161 & 0.039 & 1.4 & 3.5 & 49.2 \\
\hline & P17 & 1161 & 0.033 & 1.3 & 3.6 & 50.9 \\
\hline \multicolumn{7}{|l|}{ Amanaki } \\
\hline FU2-HY-33 tow-yo & $\mathrm{P} 1$ & 1875 & 0.038 & 2.9 & 36.6 & 73.5 \\
\hline \multirow[t]{12}{*}{$S W$ to $N E$} & $\mathrm{P} 2$ & - & - & - & - & - \\
\hline & P3 & 1869 & 0.037 & 2.5 & 33.8 & 67.4 \\
\hline & P4 & $3-$ & - & - & - & - \\
\hline & P5 & 1905 & 0.038 & 3.0 & 35.8 & 73.1 \\
\hline & P6 & - & - & - & - & - \\
\hline & P7 & 1905 & 0.036 & 2.4 & 31.3 & 68.0 \\
\hline & P8 & 1910 & 0.037 & 2.9 & 33.8 & \\
\hline & P9 & - & - & - & - & - \\
\hline & P10 & 1925 & 0.034 & 2.2 & 28.3 & \\
\hline & P11 & - & - & - & - & - \\
\hline & P12 & 1900 & 0.040 & 3.1 & 34.6 & \\
\hline & P13 & - & - & - & - & - \\
\hline
\end{tabular}

Fatu-Kapa

\begin{tabular}{lllllll} 
FU3-HY-05 tow-yo & P1 & 1470 & 0.017 & 0.8 & 5.8 & - \\
SW to NE & P2 & 1467 & 0.020 & 1.0 & 5.9 & - \\
& P3 & 1470 & 0.019 & 0.9 & 6.4 & - \\
& P4 & 1472 & 0.018 & 2.5 & 10.0 & - \\
& P5 & 1470 & 0.023 & 3.8 & 12.0 & - \\
& P6 & 1468 & 0.021 & 3.8 & 11.5 & - \\
\hline
\end{tabular}




\begin{tabular}{cccccc}
\hline P7 & 1470 & 0.021 & 3.4 & 9.8 & - \\
P8 & 1524 & 0.024 & 5.1 & 11.5 & - \\
P8 & 1514 & 0.023 & 4.5 & 12.7 & - \\
P9 & 1476 & 0.022 & 3.9 & 10.7 & - \\
P9 & 1516 & 0.021 & 3.7 & 10.8 & - \\
P10 & 1523 & 0.023 & 4.8 & 11.1 & - \\
P11 & 1525 & 0.034 & - & - & - \\
P11 & 1499 & 0.032 & 8.1 & 14.4 & - \\
P12 & 1510 & 0.022 & 6.7 & 13.7 & - \\
P12 & 1490 & 0.022 & 5.5 & 11.5 & - \\
\hline
\end{tabular}

Table 4 : Temporal variability of tracers at stations reoccupied at one year interval

\begin{tabular}{lcccc}
\hline & \multicolumn{2}{c}{ Fatu Kapa maxima } & \multicolumn{2}{c}{ Tasi Tulo maxima } \\
\cline { 2 - 5 } & $\mathbf{2 0 1 1}$ & $\mathbf{2 0 1 2}$ & $\mathbf{2 0 1 1}$ & $\mathbf{2 0 1 2}$ \\
& $($ FU2-HY-38) & $($ FU3-HY-08) & (FU2-HY-13) & (FU3-HY-13) \\
& 1375 & 1525 & 1400 & 1500 \\
\hline Plume depth (m) & 5.9 & 6.0 & 3.3 & 4.8 \\
$\mathrm{CH}_{4}(\mathrm{nM})$ & 23.8 & 17.1 & 9.9 & 14.3 \\
TDM (nM) & 0.030 & 0.024 & - & - \\
Nephel (NTU) & & & & \\
\hline
\end{tabular}




\section{Highlights}

- extensive and diverse hydrothermal activity in the SW-Pacific

- importance of back-arc hydrothermal systems for the global ocean chemistry and biogeochemical cycles

- ${ }^{3} \mathrm{He}$ Tonga-Fiji regional plume

- FSC sets the western boundary of the hydrothermally active zone 


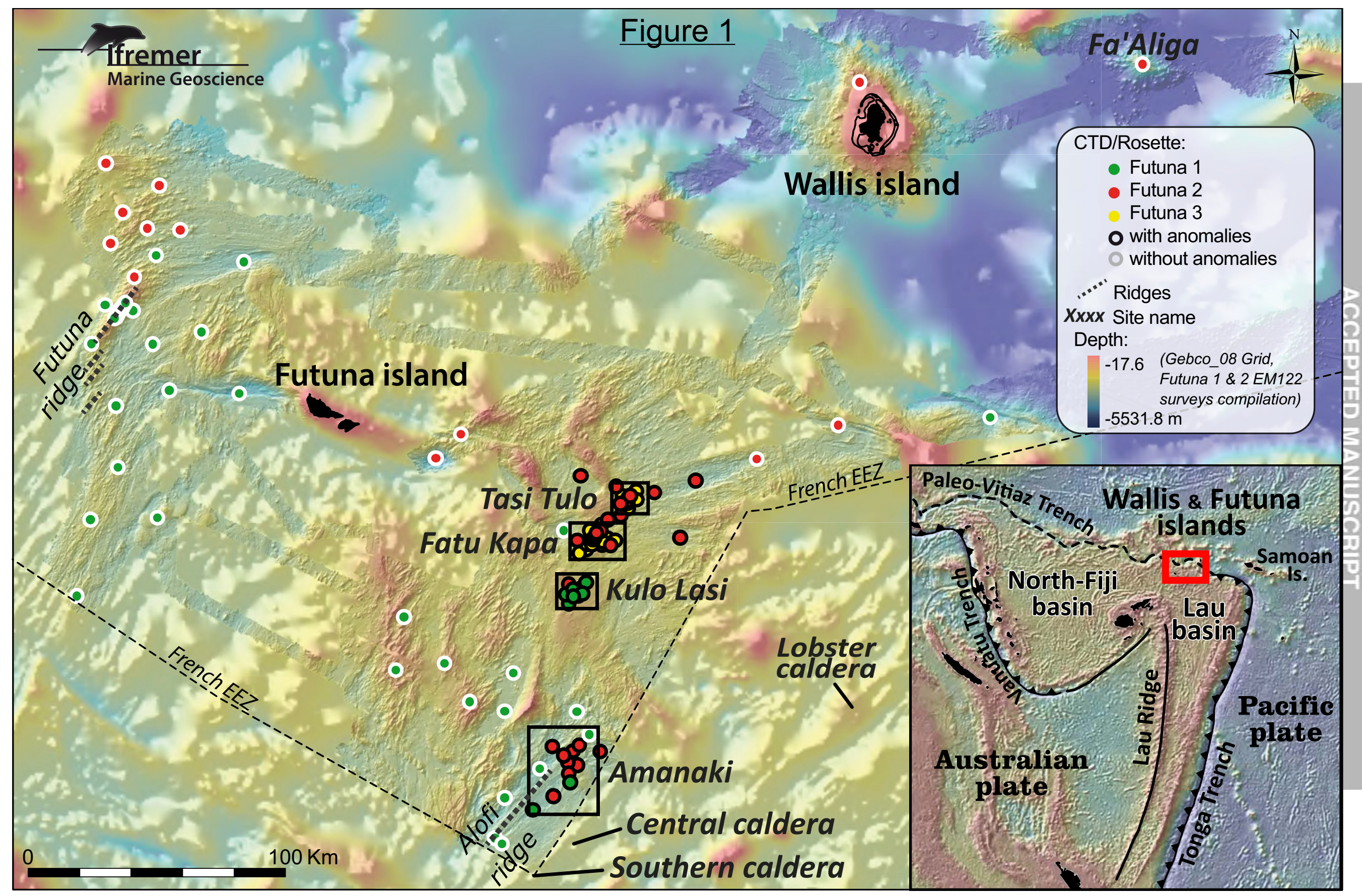




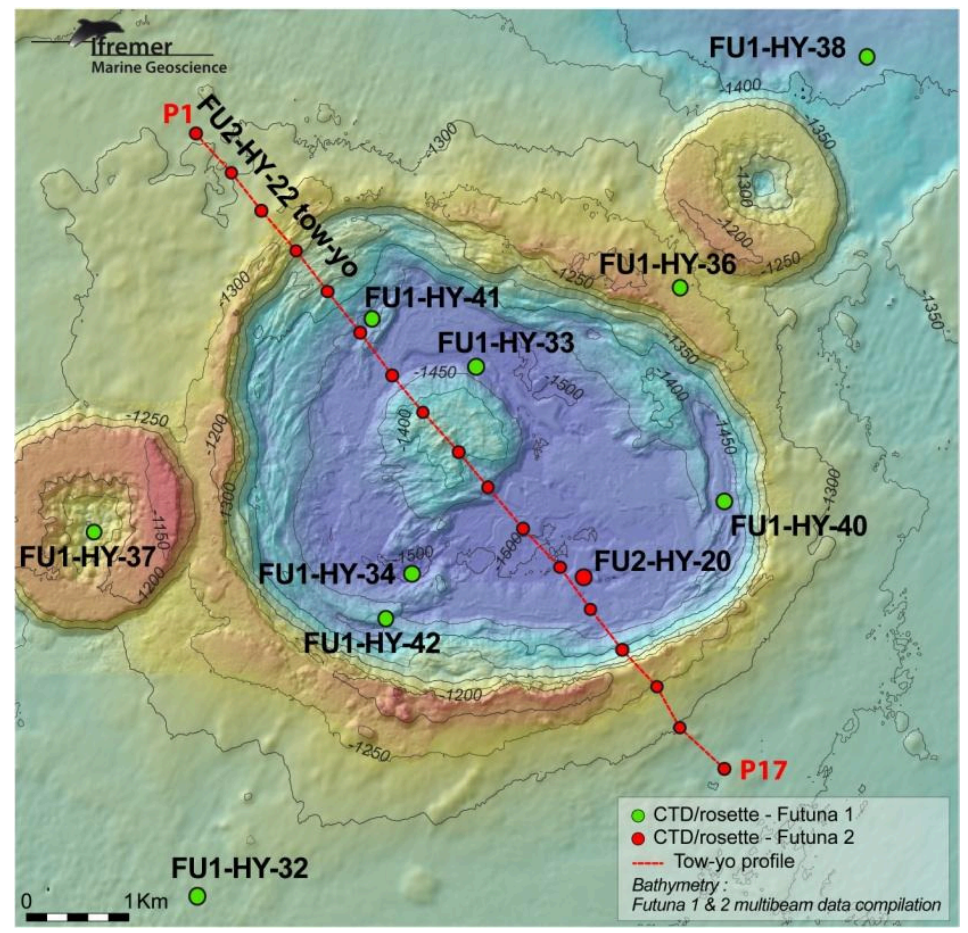

A

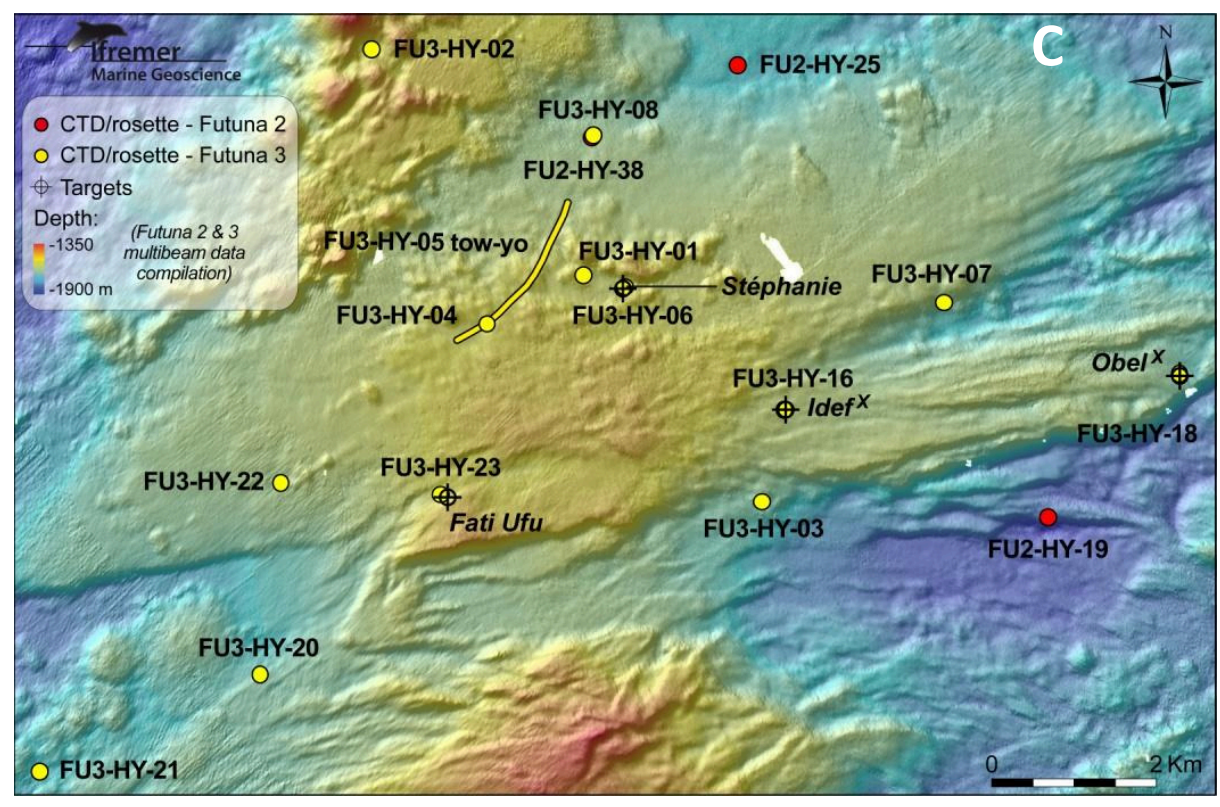

Figure 2
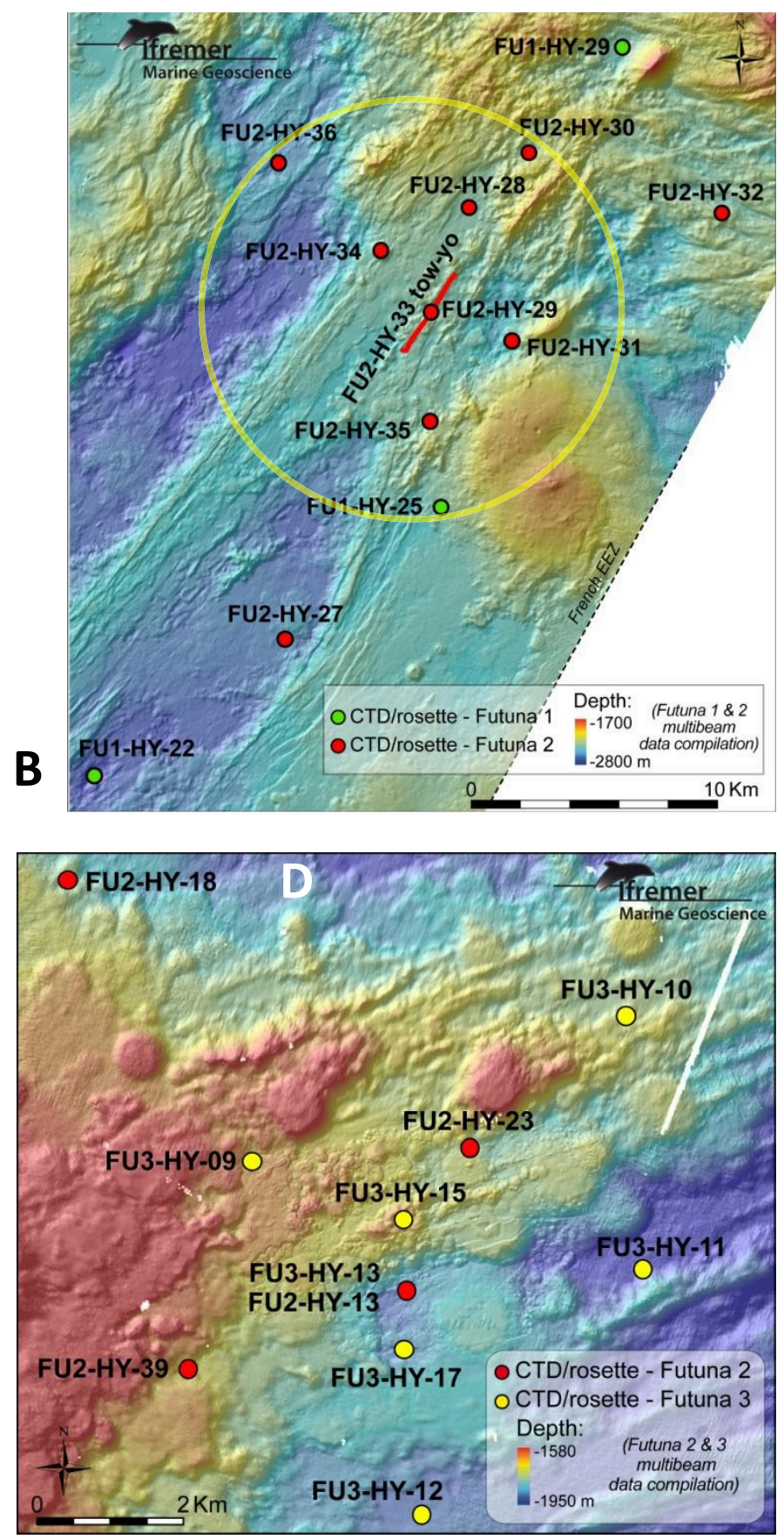

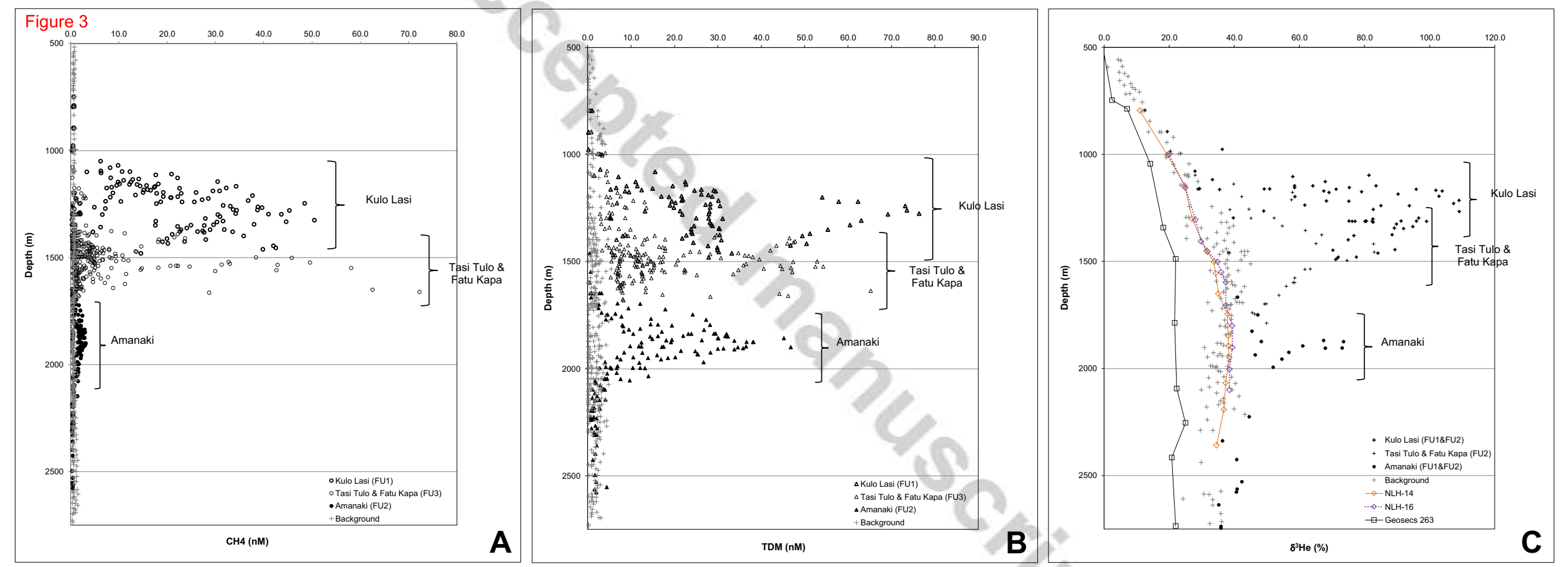
Figure 4

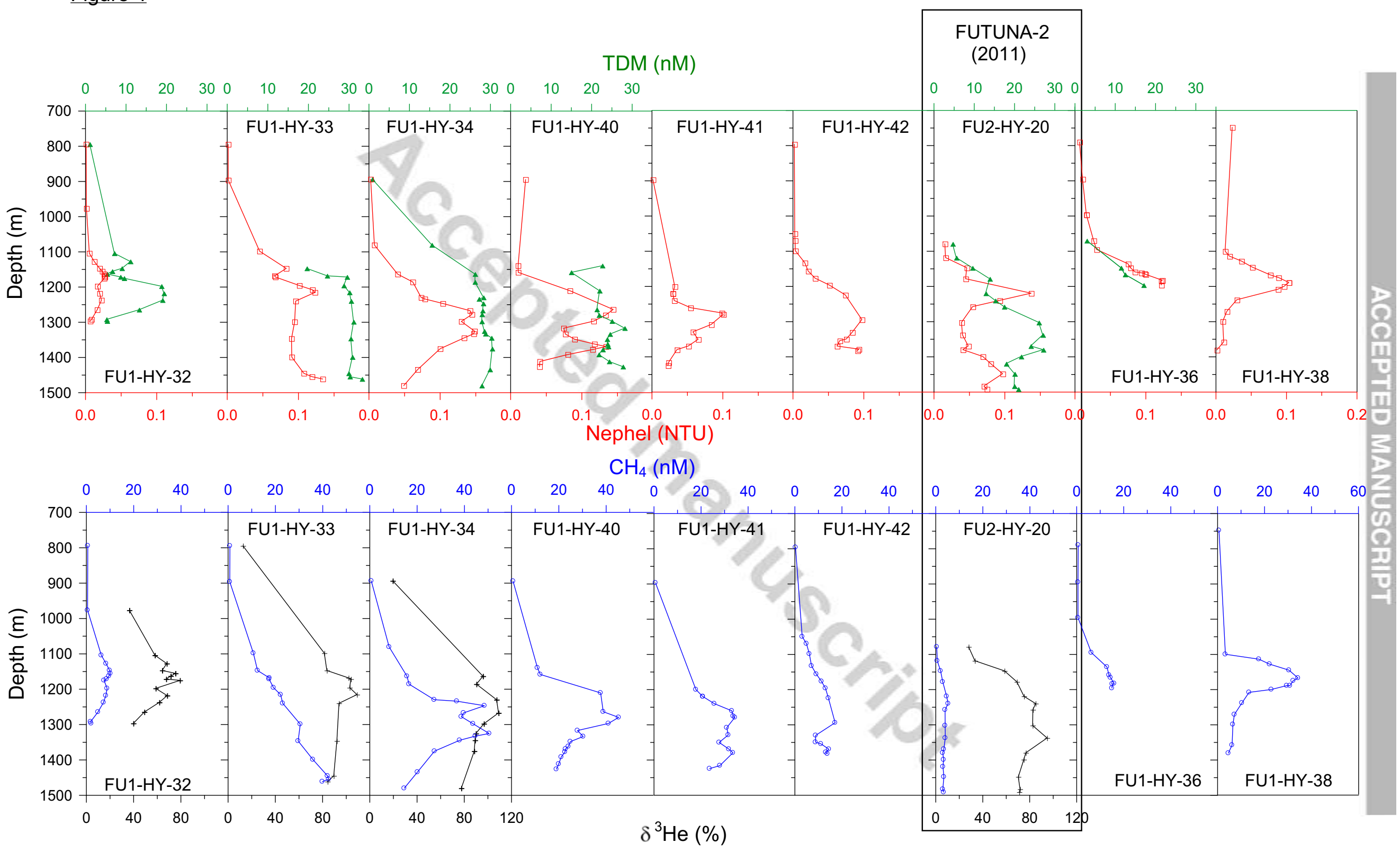




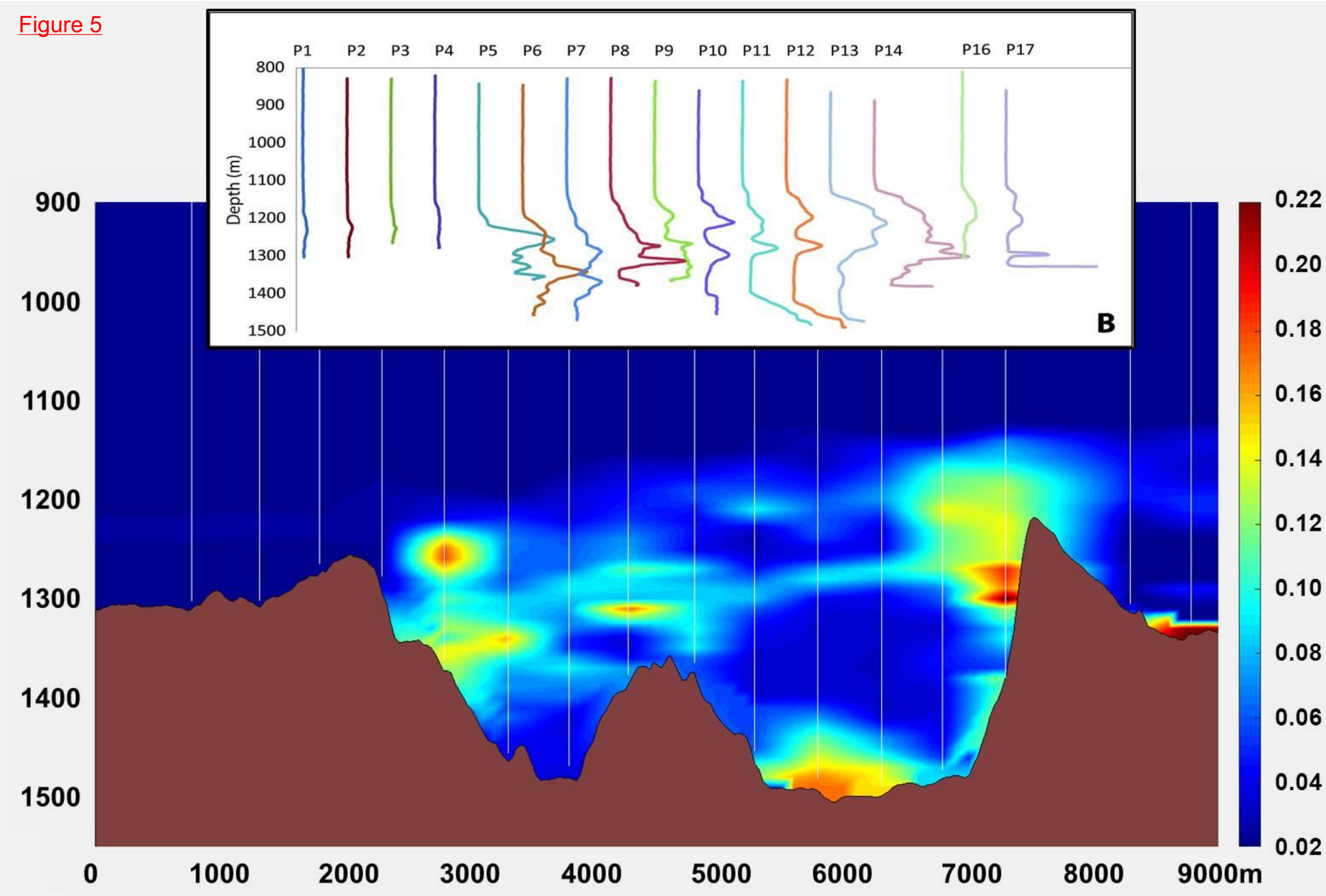



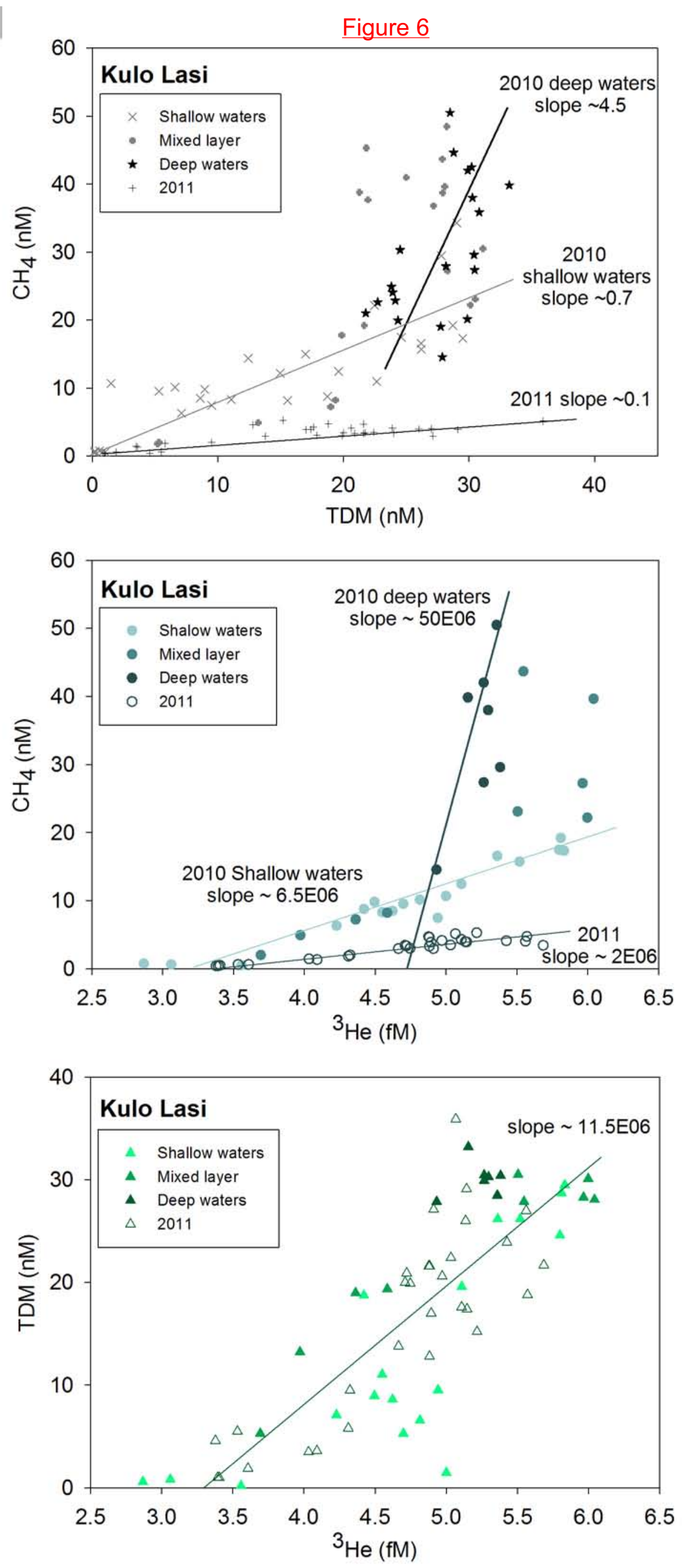


\section{Figure 7}

TDM (nM)

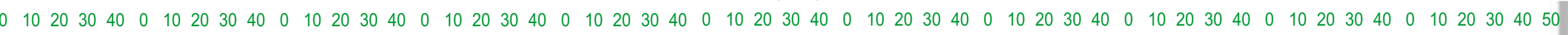

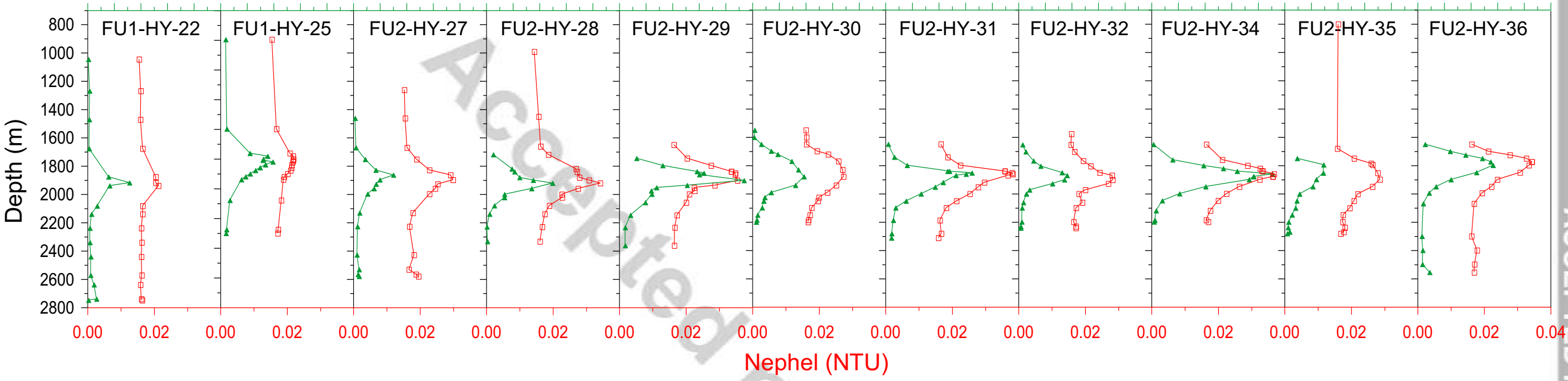

$\mathrm{CH}_{4}(\mathrm{nM})$

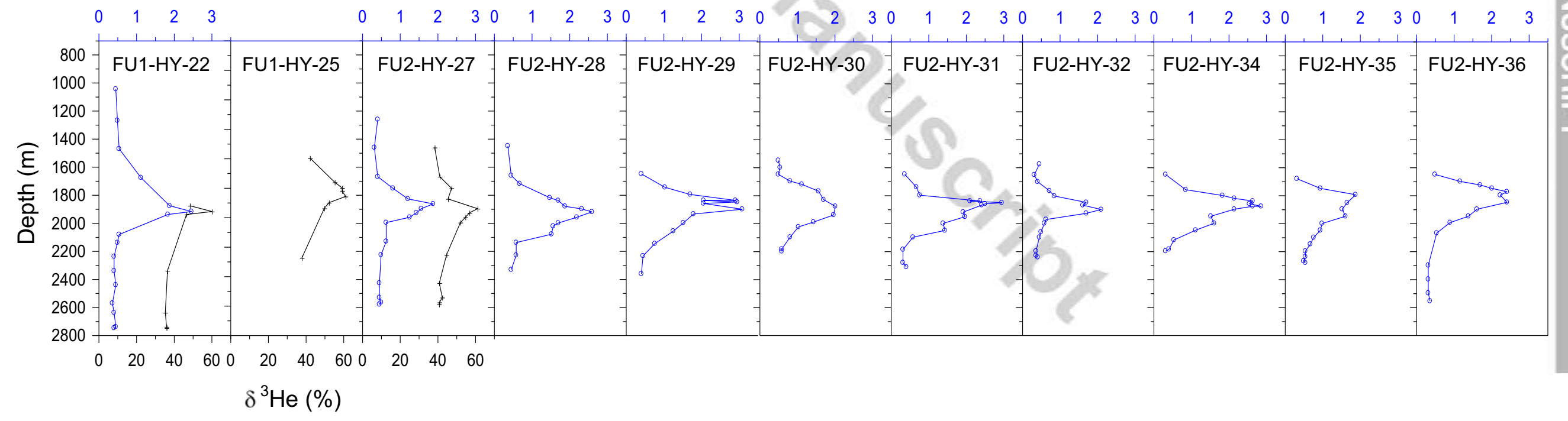


Figure 8

$\mathrm{CH}_{4}(\mathrm{nM})$

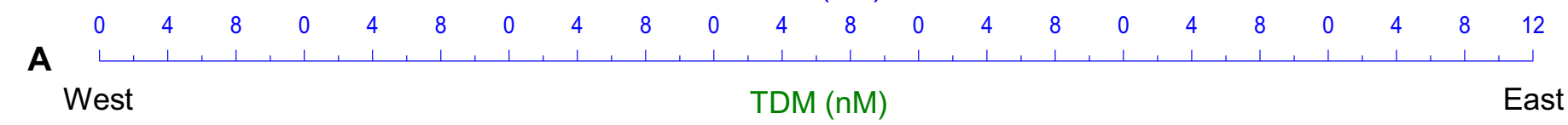

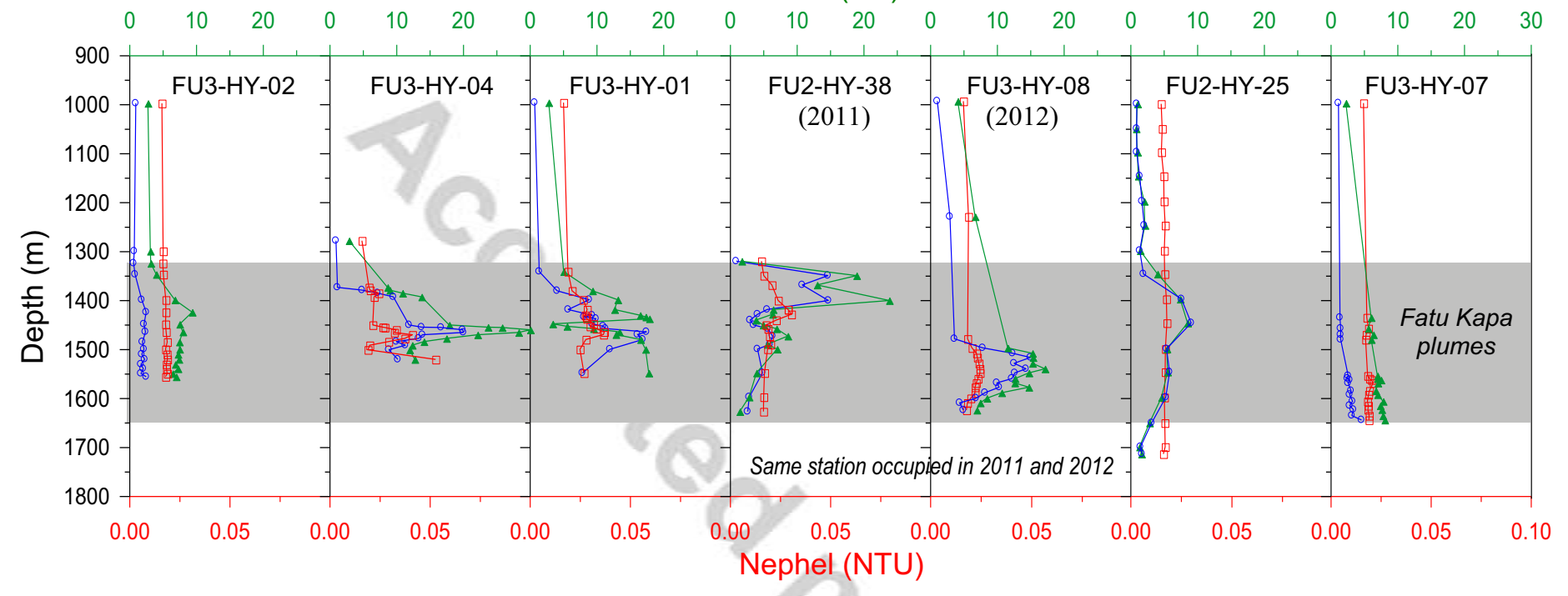

$\mathrm{CH}_{4}(\mathrm{nM})$

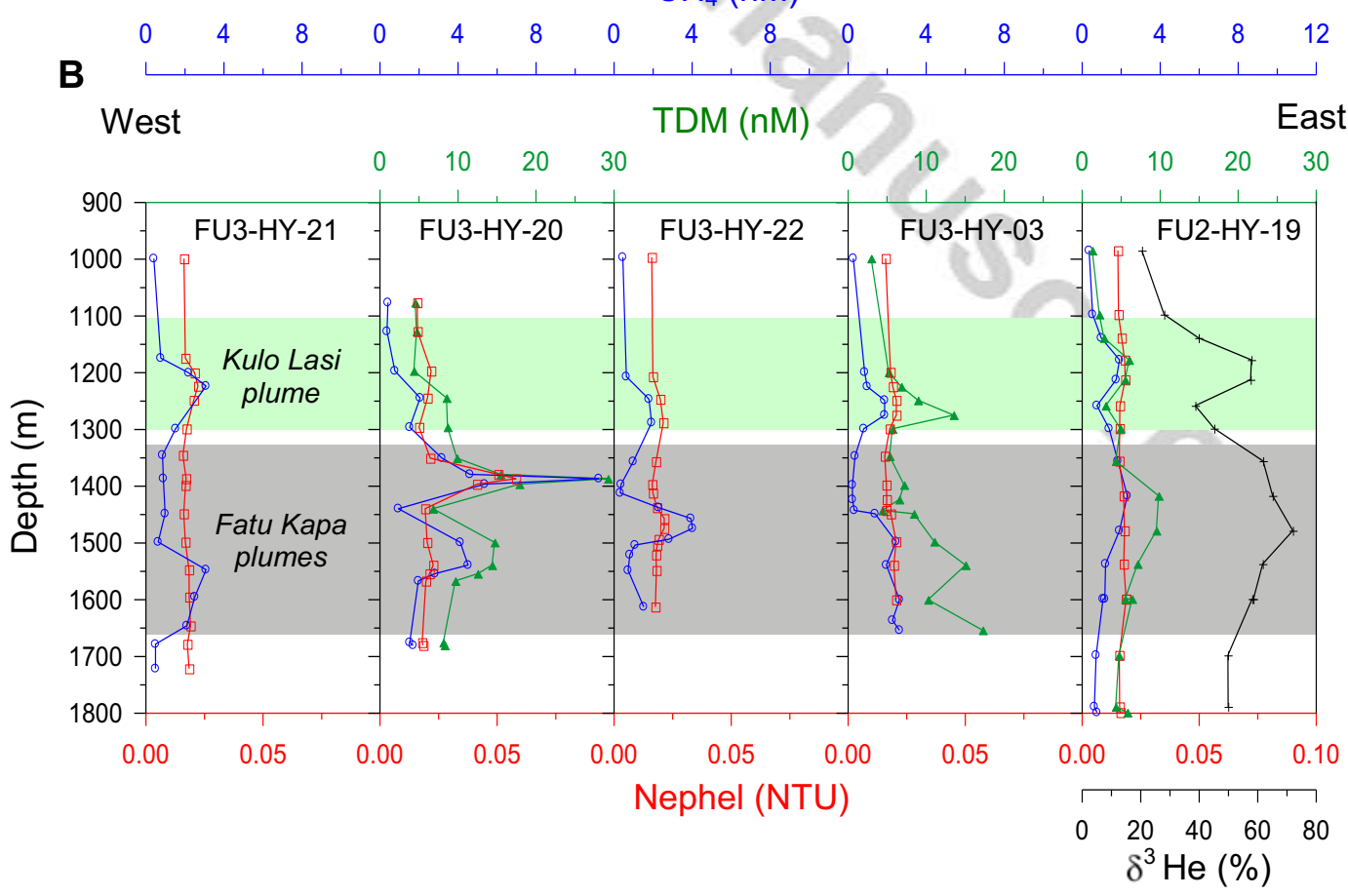


Figure 9

TDM (nM)
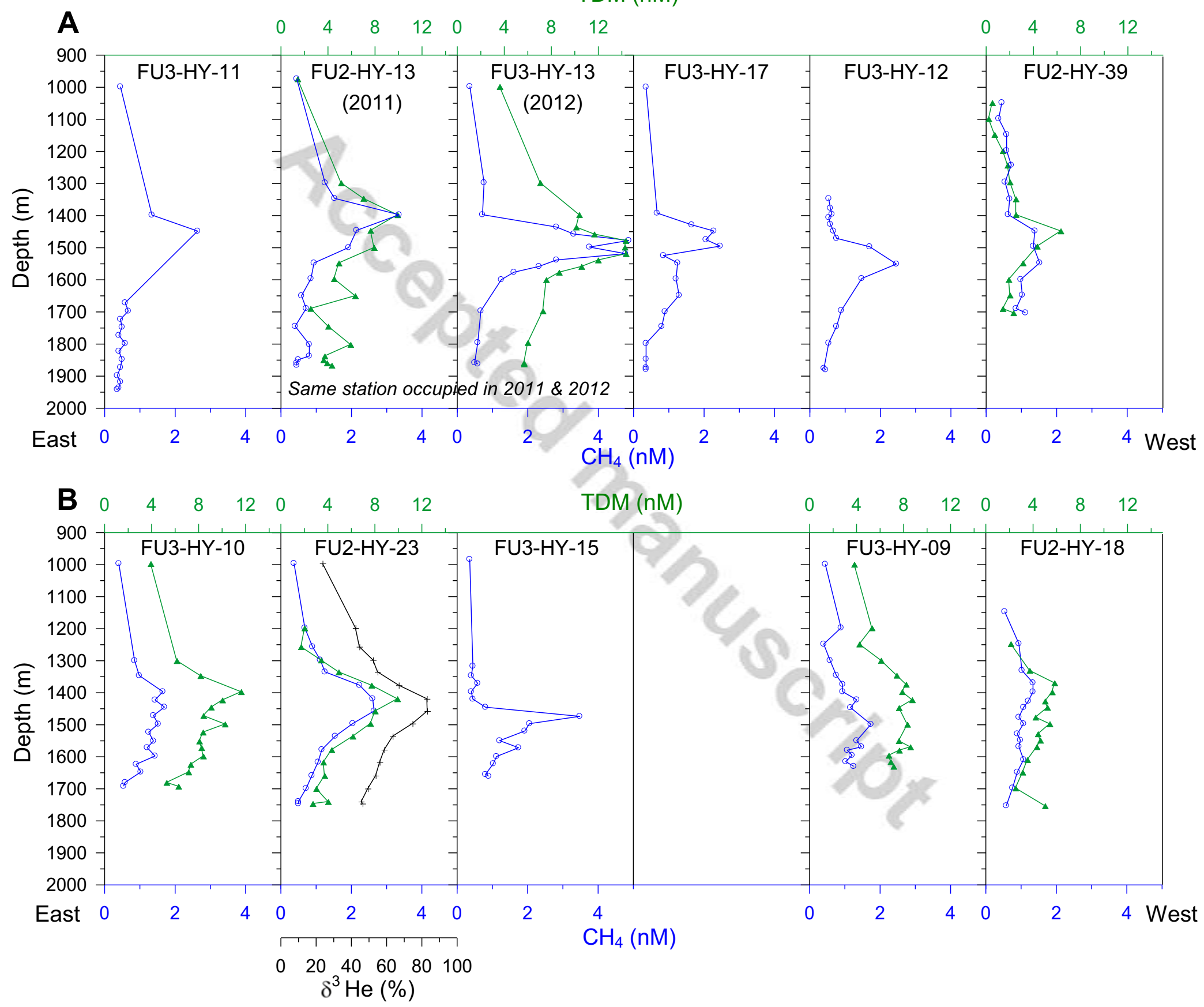